\title{
Global atmospheric model for mercury including oxidation by bromine atoms
}

\author{
C. D. Holmes ${ }^{1}$, D. J. Jacob ${ }^{1}$, E. S. Corbitt ${ }^{1}$, J. Mao ${ }^{1}$, X. Yang ${ }^{2}$, R. Talbot ${ }^{3}$, and F. Slemr ${ }^{4}$ \\ ${ }^{1}$ Department of Earth and Planetary Sciences and School of Engineering and Applied Sciences, Harvard University, \\ Cambridge, MA, USA \\ ${ }^{2}$ Department of Chemistry, Cambridge University, Cambridge, England \\ ${ }^{3}$ Institute for the Study of Earth, Oceans, and Space, University of New Hampshire, Durham, NH, USA \\ ${ }^{4}$ Max Planck Institute for Chemistry, Air Chemistry Division, Mainz, Germany
}

Received: 2 August 2010 - Published in Atmos. Chem. Phys. Discuss.: 24 August 2010

Revised: 18 November 2010 - Accepted: 3 December 2010 - Published: 17 December 2010

\begin{abstract}
Global models of atmospheric mercury generally assume that gas-phase $\mathrm{OH}$ and ozone are the main oxidants converting $\mathrm{Hg}^{0}$ to $\mathrm{Hg}^{\mathrm{II}}$ and thus driving mercury deposition to ecosystems. However, thermodynamic considerations argue against the importance of these reactions. We demonstrate here the viability of atomic bromine $(\mathrm{Br})$ as an alternative $\mathrm{Hg}^{0}$ oxidant. We conduct a global 3-D simulation with the GEOS-Chem model assuming gas-phase $\mathrm{Br}$ to be the sole $\mathrm{Hg}^{0}$ oxidant $(\mathrm{Hg}+\mathrm{Br}$ model $)$ and compare to the previous version of the model with $\mathrm{OH}$ and ozone as the sole oxidants $\left(\mathrm{Hg}+\mathrm{OH} / \mathrm{O}_{3}\right.$ model $)$. We specify global 3-D Br concentration fields based on our best understanding of tropospheric and stratospheric $\mathrm{Br}$ chemistry. In both the $\mathrm{Hg}+\mathrm{Br}$ and $\mathrm{Hg}+\mathrm{OH} / \mathrm{O}_{3}$ models, we add an aqueous photochemical reduction of $\mathrm{Hg}^{\mathrm{II}}$ in cloud to impose a tropospheric lifetime for mercury of 6.5 months against deposition, as needed to reconcile observed total gaseous mercury (TGM) concentrations with current estimates of anthropogenic emissions. This added reduction would not be necessary in the $\mathrm{Hg}+\mathrm{Br}$ model if we adjusted the $\mathrm{Br}$ oxidation kinetics downward within their range of uncertainty. We find that the $\mathrm{Hg}+\mathrm{Br}$ and $\mathrm{Hg}+\mathrm{OH} / \mathrm{O}_{3}$ models are equally capable of reproducing the spatial distribution of TGM and its seasonal cycle at northern mid-latitudes. The $\mathrm{Hg}+\mathrm{Br}$ model shows a steeper decline of TGM concentrations from the tropics to southern mid-latitudes. Only the $\mathrm{Hg}+\mathrm{Br}$ model can reproduce the springtime depletion and summer rebound of TGM observed at polar sites; the snowpack component of GEOS-Chem suggests that $40 \%$ of $\mathrm{Hg}^{\mathrm{II}}$ deposited to snow in the Arctic is transferred to the ocean and land reservoirs, amounting to a
\end{abstract}

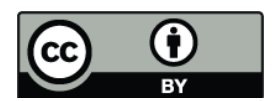

Correspondence to: C. D. Holmes (cdholmes@post.harvard.edu) net deposition flux to the Arctic of $60 \mathrm{Mg} \mathrm{a}^{-1}$. Summertime events of depleted $\mathrm{Hg}^{0}$ at Antarctic sites due to subsidence are much better simulated by the $\mathrm{Hg}+\mathrm{Br}$ model. Model comparisons to observed wet deposition fluxes of mercury in the US and Europe show general consistency. However the $\mathrm{Hg}+\mathrm{Br}$ model does not capture the summer maximum over the southeast US because of low subtropical $\mathrm{Br}$ concentrations while the $\mathrm{Hg}+\mathrm{OH} / \mathrm{O}_{3}$ model does. Vertical profiles measured from aircraft show a decline of $\mathrm{Hg}^{0}$ above the tropopause that can be captured by both the $\mathrm{Hg}+\mathrm{Br}$ and $\mathrm{Hg}+\mathrm{OH} / \mathrm{O}_{3}$ models, except in Arctic spring where the observed decline is much steeper than simulated by either model; we speculate that oxidation by $\mathrm{Cl}$ species might be responsible. The $\mathrm{Hg}+\mathrm{Br}$ and $\mathrm{Hg}+\mathrm{OH} / \mathrm{O}_{3}$ models yield similar global budgets for the cycling of mercury between the atmosphere and surface reservoirs, but the $\mathrm{Hg}+\mathrm{Br}$ model results in a much larger fraction of mercury deposited to the Southern Hemisphere oceans.

\section{Introduction}

Mercury is a neurotoxic pollutant that is dispersed globally by atmospheric transport. Emissions are mostly elemental mercury $\left(\mathrm{Hg}^{0}\right)$ and atmospheric observations of $\mathrm{Hg}^{0}$ imply an atmospheric lifetime on the order of one year (Lindberg et al., 2007). The oxidized product $\mathrm{Hg}^{\mathrm{II}}$ is highly water soluble and deposits rapidly through precipitation and surface uptake. Understanding the global budget of atmospheric mercury and the source-receptor relationships for mercury deposition therefore requires global atmospheric transport models with accurate redox chemistry.

Published by Copernicus Publications on behalf of the European Geosciences Union. 
A fundamental limitation of current models is the uncertainty in the atmospheric chemistry of mercury (Lin et al., 2006; Ariya et al., 2008, 2009). Atmospheric observations imply that oxidation of $\mathrm{Hg}^{0}$ to $\mathrm{Hg}^{\mathrm{II}}$ must be photochemical (Shia et al., 1999; Selin et al., 2007). Models generally assume that gas-phase $\mathrm{OH}$ and ozone are the main oxidants, and also include aqueous-phase reduction of $\mathrm{Hg}^{\mathrm{II}}$ to $\mathrm{Hg}^{0}$ that competes with deposition as a sink for $\mathrm{Hg}^{\mathrm{II}}$ (Bergan and Rodhe, 2001; Petersen et al., 2001; Cohen et al., 2004; Lin et al., 2006; Seigneur et al., 2006; Selin et al., 2007; Pongprueksa et al., 2008). However, recent work suggests that gas-phase oxidation of $\mathrm{Hg}^{0}$ by $\mathrm{OH}$ and $\mathrm{O}_{3}$ is too slow to be of atmospheric relevance (Calvert and Lindberg, 2005; Hynes et al., 2009). Heterogeneous oxidation in clouds and aerosols is conceivable but hypothetical (Calvert and Lindberg, 2005; Snider et al., 2008; Ariya et al., 2009). There is also no accepted kinetics or mechanism for $\mathrm{Hg}^{\mathrm{II}}$ atmospheric reduction (Ariya et al., 2009; Hynes et al., 2009). Present-day measurement techniques cannot determine the molecular identity of atmospheric $\mathrm{Hg}^{\mathrm{II}}$ oxidation products, but instead quantify all gas-phase $\mathrm{Hg}^{\mathrm{II}}$ as reactive gaseous mercury (RGM).

Holmes et al. (2006) proposed that gas-phase $\mathrm{Br}$ atoms might be the dominant global oxidant of $\mathrm{Hg}^{0}$, with most of the oxidation taking place in the free troposphere. Several pieces of evidence support this idea. Oxidation of $\mathrm{Hg}^{0}$ by $\mathrm{Br}$ is thought to explain the mercury depletion events (MDEs) in polar spring (Goodsite et al., 2004; Steffen et al., 2008; Xie et al., 2008). Diurnal patterns of $\mathrm{Hg}^{\mathrm{II}}$ in the marine boundary layer (MBL) are consistent with oxidation by $\mathrm{Br}$ (Hedgecock et al., 2005; Holmes et al., 2009). Column measurements suggest a background concentration of $0.5-2 \mathrm{ppt} \mathrm{BrO}$ in the free troposphere (Pundt et al., 2002; Van Roozendael et al., 2002; Sinnhuber et al., 2005) that could be accounted for by photolysis and oxidation of bromocarbons (Yang et al., 2005). Br atom concentrations deduced from photochemical equilibrium with this background $\mathrm{BrO}$ could yield an $\mathrm{Hg}^{0}$ atmospheric lifetime of less than a year (Holmes et al., 2006). The lower stratosphere also contains elevated BrO (Salawitch et al., 2005), which might explain the rapid depletion of $\mathrm{Hg}^{0}$ observed above the tropopause (Talbot et al., 2008).

Constructing a plausible global model of $\mathrm{Hg}+\mathrm{Br}$ chemistry is challenging because of the large range of reported $\mathrm{Hg}+\mathrm{Br}$ kinetics (Holmes et al., 2006; Ariya et al., 2008; Hynes et al., 2009) and because of uncertainties in the concentrations of atmospheric Br. Gaseous inorganic bromine $\left(\mathrm{Br}_{\mathrm{y}}\right)$ originates from atmospheric degradation of bromocarbons and debromination of sea-salt aerosol (von Glasow et al., 2002; Pszenny et al., 2004; Yang et al., 2005). Shortlived bromocarbons are thought to dominate the supply of $\mathrm{Br}_{\mathrm{y}}$ in the free troposphere and lower stratosphere; these include $\mathrm{CHBr}_{3}$ and $\mathrm{CH}_{2} \mathrm{Br}_{2}$ emitted by the ocean and $\mathrm{CH}_{3} \mathrm{Br}$ of both biogenic and anthropogenic origin (Yang et al., 2005). Sea salt dominates $\mathrm{Br}_{\mathrm{y}}$ supply in the MBL. $\mathrm{Br}_{\mathrm{y}}$ cycles between radical forms $(\mathrm{Br}$ and $\mathrm{BrO})$ and non-radical reservoir species $\left(\mathrm{HOBr}, \mathrm{HBr}, \mathrm{BrNO}_{3}, \mathrm{BrNO}_{2}\right.$, and $\left.\mathrm{Br}_{2}\right)$ (Pszenny et al., 2004). $\mathrm{Br}$ and $\mathrm{BrO}$ are in fast photochemical equilibrium during daytime and disappear into the reservoir species at night. Heterogeneous reactions of $\mathrm{HOBr}, \mathrm{HBr}$, and $\mathrm{BrNO}_{3}$ on aerosols could also be important for maintaining radical concentrations (von Glasow et al., 2004; Yang et al., 2005). $\mathrm{Br}_{\mathrm{y}}$ is eventually removed from the atmosphere by wet and dry deposition.

Three previous global mercury model studies have included $\mathrm{Br}$ as an $\mathrm{Hg}^{0}$ oxidant in addition to $\mathrm{OH}$ and $\mathrm{O}_{3}$ (Ariya et al., 2004; Seigneur and Lohman, 2008; Dastoor et al., 2008). The studies of Ariya et al. (2004) and Dastoor et al. (2008) focused on simulation of Arctic MDEs, where the importance of $\mathrm{Br}$ is well established. Seigneur and Lohman (2008) evaluated the sensitivity of the simulated interhemispheric and vertical gradients of $\mathrm{Hg}^{0}$ to the $\mathrm{Hg}+\mathrm{Br}$ reaction kinetics. Their simulated mean surface $\mathrm{Hg}^{0}$ concentrations changed by $20-40 \%$ across the range of the kinetic data (Ariya et al., 2002; Donohoue et al., 2006), with the best results obtained with the slow kinetics. In contrast, Dastoor et al. (2008) reported that the fast kinetics gave a better simulation of $\mathrm{Hg}^{0}$ in the Arctic at Alert, Canada. Seigneur and Lohman (2008) also presented a sensitivity test in which $\mathrm{Br}$ was the sole oxidant of $\mathrm{Hg}^{0}$. This showed an unrealistic peak of $\mathrm{Hg}^{0}$ in the tropics and minima at the poles.

Here we use the GEOS-Chem global chemical transport model (Selin et al., 2008) to evaluate whether a model with gas-phase $\mathrm{Br}$ as the sole $\mathrm{Hg}^{0}$ oxidant can in fact be consistent with atmospheric observations. The above model studies derived their tropospheric bromine concentrations from satellite observations of $\mathrm{BrO}$ columns (Chance, 1998; Burrows et al., 1999), which feature polar maxima of BrO. Recent aircraft observations in the Arctic, however, show that the troposphere contributes less to these polar maxima than previously expected (Salawitch et al., 2010), so earlier models likely overestimated tropospheric $\mathrm{Hg}^{0}$ oxidation at high latitudes. Here we use a combination of field measurements and process-based models to estimate the distribution of $\mathrm{Br}$ from the surface to the stratosphere. We also describe several other recent improvements to the GEOS-Chem mercury model including updated anthropogenic emissions, mechanistic uptake by sea-salt aerosol, scavenging by snow and ice, and a coupled snowpack reservoir. We evaluate the ability of this new model version to reproduce atmospheric observations through comparisons with multiple data sets.

\section{Model description}

The previous version of the GEOS-Chem atmosphere-oceanland mercury model (v7.04) was described by Selin et al. (2008). The model includes a global 3-D atmosphere (here $4^{\circ} \times 5^{\circ}$ horizontal resolution, 55 vertical levels, hourly time steps) coupled to 2-D surface ocean and soil reservoirs. The atmospheric component is driven by assimilated meteorological data from the Goddard Earth Observing System 
(GEOS) of the NASA Global Modeling and Assimilation Office (GMAO). It includes three transported species: $\mathrm{Hg}^{0}$, $\mathrm{Hg}^{\mathrm{II}}$, and inert, nonvolatile particulate mercury $\left(\mathrm{Hg}_{\mathrm{P}}\right)$. The surface ocean component (Strode et al., 2007) includes three species: $\mathrm{Hg}^{0}$, reactive dissolved $\mathrm{Hg}^{\mathrm{II}}$, and inert particlebound $\mathrm{Hg}_{\mathrm{P}}$. These ocean species undergo chemical interconversion and vertical exchange with the atmosphere and with a deep ocean reservoir of fixed mercury concentrations. Horizontal transport in the ocean is neglected. Natural soil mercury concentrations are specified on the $4^{\circ} \times 5^{\circ}$ grid by steady state of emissions and deposition in the preindustrial atmosphere (Selin et al., 2008). They are augmented for present-day on the basis of the modeled deposition patterns of anthropogenic mercury.

In the present model we have updated the emissions, atmospheric chemistry, and deposition modules used by Selin et al. (2008). We elaborate on these improvements below. We have also updated the transport component by using meteorological input from the GEOS-5 assimilation data, which have $0.5^{\circ} \times 0.67^{\circ}$ horizontal resolution and 72 vertical layers. As before, we degrade the resolution to $4^{\circ} \times 5^{\circ}$ and 47 layers for computational expediency. Tracer transport algorithms are from the current GEOS-Chem version (8.02.03), which includes improved cross-tropopause transport (MacKenzie, 2009) and a non-local parameterization of boundary layer mixing (Lin and McElroy, 2010). Figure 1 presents our updated global mercury budget, which we will discuss in Sect. 4.

\subsection{Emissions}

Selin et al. (2008) previously used the GEIA anthropogenic emissions for 2000 (Pacyna et al., 2006) but increased $\mathrm{Hg}^{0}$ emissions globally by $30 \%$ (by $50 \%$ in China) to $3400 \mathrm{Mg} \mathrm{a}^{-1}$ total $\mathrm{Hg}$ in order to accommodate atmospheric observations. Those emissions exceed the 1900$2600 \mathrm{Mg} \mathrm{a}^{-1}$ range of recent estimates and are likely too high (Mason and Sheu, 2002; Streets et al., 2009; Pacyna et al., 2010; Pirrone et al., 2010). Here we use the Streets et al. (2009) global inventory for 2006 partitioned into 17 regions; emissions within each region follow the GEIA distribution. In addition, $\mathrm{Hg}^{0}$ emissions from artisanal gold mining total $450 \mathrm{Mg} \mathrm{a}^{-1}$ (Hylander and Meili, 2005; Selin et al., 2008), which is very close to the independent estimate of $400 \mathrm{Mg} \mathrm{a}^{-1}$ by Telmer and Veiga (2009). Our anthropogenic emissions thus total $1300 \mathrm{Mg} \mathrm{a}^{-1} \mathrm{Hg}^{0}, 650 \mathrm{Mg} \mathrm{a}^{-1} \mathrm{Hg}^{\mathrm{II}}$, and $100 \mathrm{Mg} \mathrm{a}^{-1} \mathrm{Hg}_{\mathrm{P}}$. While these are $30 \%$ lower than in Selin et al. (2008), our simulation remains consistent with the observed $\mathrm{Hg}^{0}$ concentrations (as we will show below) because changes in the redox chemistry prolong the $\mathrm{Hg}^{0}$ lifetime.

The soil emissions specified by Selin et al. (2008) were an exponential function of both soil temperature and solar radiation, producing a strong summer peak. With the smaller anthropogenic emissions and slower oxidation in the present model, these emissions would result in a summer $\mathrm{Hg}^{0}$ max-

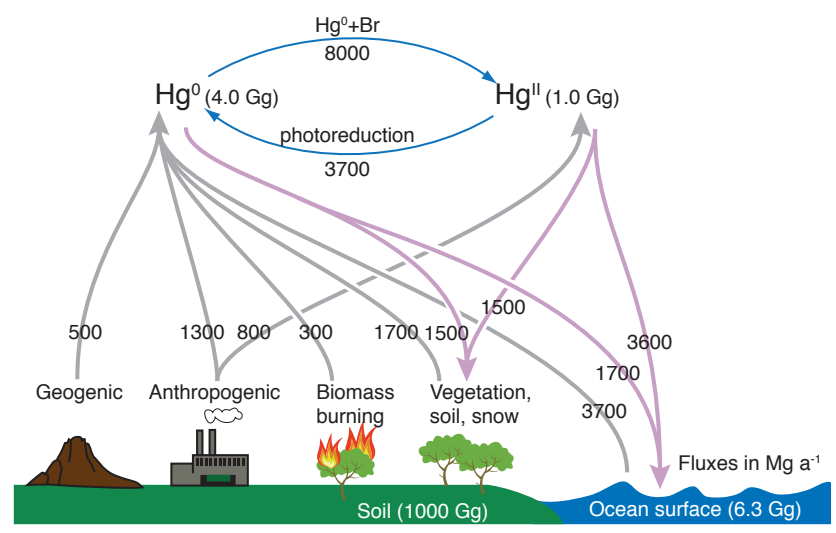

Fig. 1. Global budget of atmospheric mercury derived from this work. $\mathrm{Hg}^{\mathrm{II}}$ here includes gaseous and particulate forms, plus a negligible contribution $(1 \mathrm{Mg})$ from inert particulate mercury.

imum at northern mid-latitudes that is at odds with observations. Here we specify soil emission $E$ as a function of solar radiation only following Zhang et al. (2001),

$E=\beta C_{\mathrm{s}} \exp \left(\alpha R_{\mathrm{g}}\right)$,

where $C_{\mathrm{s}}$ is the soil mercury concentration $\left(\mathrm{g} \mathrm{g}^{-1}\right), R_{\mathrm{g}}$ is the solar radiation flux at the ground, and $\alpha=1.1 \times 10^{3} \mathrm{~m}^{2} \mathrm{~W}^{-1}$. The scaling factor $\beta=0.02 \mathrm{~g} \mathrm{~m}^{-2} \mathrm{~h}^{-1}$ is derived here from global mass balance in the preindustrial period, as described by Selin et al. (2008). With this change, simulated $\mathrm{Hg}^{0}$ concentrations follow the observed seasonal cycle, but total present-day soil emissions, $1200 \mathrm{Mg} \mathrm{a}^{-1}$, are unchanged from Selin et al. (2008).

As in Selin et al. (2008), soil and vegetation emit an additional $260 \mathrm{Mg} \mathrm{a}^{-1}$ through rapid photoreduction of deposited $\mathrm{Hg}^{\mathrm{II}}$. Biomass burning emits $300 \mathrm{Mg} \mathrm{a}^{-1}$ following the distribution of biomass burning $\mathrm{CO}$, using a new $\mathrm{Hg} / \mathrm{CO}$ emission ratio of $100 \mathrm{nmol} \mathrm{mol}^{-1}$ derived in Sect. 3.5. Friedli et al. (2009) estimate larger biomass burning emissions of $675 \pm 240 \mathrm{Mg} \mathrm{a}^{-1}$ based on satellite-derived fire area and biome-specific emission factors, but our results here are not sensitive to this difference because these emissions are relatively small in any case. The model no longer includes emissions through plant transpiration because of field evidence that this process is unimportant (Gustin et al., 2004).

Arctic field studies find large $\mathrm{Hg}^{0}$ emissions from sunlit snowpacks in spring and summer, following surface enrichment caused by MDEs (Cobbett et al., 2007; Steffen et al., 2008, and references therein). Some of the mercury deposited during MDEs may be retained in ecosystems during snowmelt (Dommergue et al., 2003; Brooks et al., 2006; Johnson et al., 2008), but low $\mathrm{Hg}$ concentrations in lateseason snow and meltwater suggest that most of the MDEdeposited mercury returns to the atmosphere (Kirk et al., 2006). We add a snowpack reservoir on the $4^{\circ} \times 5^{\circ}$ grid 
that accumulates mercury deposition and releases it as $\mathrm{Hg}^{0}$ under sunlit conditions. The reservoir lifetime is $180 \mathrm{~d}$, decreasing to $21 \mathrm{~d}$ when $T>270 \mathrm{~K}$ to fit observations by Fain et al. $(2007,2008)$ that re-emission accelerates sharply when melting begins. This simple parameterization reproduces the seasonal cycle of atmospheric $\mathrm{Hg}^{0}$ at Arctic sites as will be shown in Sect. 3.2. We find that $60 \%$ of mercury deposited to snow is eventually reemitted and $40 \%$ enters the underlying ocean or soil. Global snow emissions are $210 \mathrm{Mg} \mathrm{a}^{-1}$.

Figure 1 summarizes model emissions. Net ocean $\mathrm{Hg}^{0}$ emissions respond dynamically to changes in emissions and chemistry and are now $2000 \mathrm{Mg} \mathrm{a}^{-1}$, which is $40 \%$ smaller than the earlier model and closer to central estimates from other studies (Lamborg et al., 2002; Mason and Sheu, 2002; Sunderland and Mason, 2007; Mason, 2009). Global mercury emissions are $8300 \mathrm{Mg} \mathrm{a}^{-1}$ if we include gross ocean $\mathrm{Hg}^{0}$ emissions or $6300 \mathrm{Mg} \mathrm{a}^{-1}$ if we include only net ocean emission.

\subsection{Chemistry}

A major update in this work is to oxidize $\mathrm{Hg}^{0}$ by $\mathrm{Br}$ atoms instead of by ozone and $\mathrm{OH}$. Table 1 lists the reactions involved. Atomic bromine initiates $\mathrm{Hg}^{0}$ oxidation in the gas phase following a mechanism described by Goodsite et al. (2004). The unstable product, $\mathrm{HgBr}$, may either dissociate or react with $\mathrm{Br}$ or $\mathrm{OH}$ to form $\mathrm{Hg}^{\mathrm{II}}$. We use kinetic coefficients from Donohoue et al. (2006), Goodsite et al. (2004) and Balabanov et al. (2005). These coefficients are at the low end of the published range (Holmes et al., 2006) and are similar to the ones chosen by Seigneur and Lohman (2008) to fit observed vertical $\mathrm{Hg}^{0}$ gradients and by Xie et al. (2008) to model MDEs. OH concentrations for the $\mathrm{HgBr}+\mathrm{OH} \rightarrow \mathrm{HgBrOH}$ reaction are archived from a GEOSChem full-chemistry simulation (Park et al., 2004).

Global bromine concentrations are specified on the model grid by combining estimates of the contributions from major precursors: bromocarbons, halons, and sea-salt aerosol bromide. For the troposphere, except the MBL, and the lower stratosphere we use monthly archived $\mathrm{Br}$ from the p-TOMCAT model with biogenic bromocarbon and methyl bromide as the only source gases (Yang et al., 2005). In the middle stratosphere and above, where halons decompose, we use archived $\mathrm{Br}$ from the NASA Global Modeling Initiative (GMI) Aura4 model with halon and methyl bromide source gases (Strahan et al., 2007). These model estimates are constrained by observations of the bromocarbon source gases (e.g. Douglass et al., 2004; WMO, 2007; Warwick et al., 2007) and standard gas-phase chemistry of $\mathrm{Br}_{\mathrm{y}}$ (Sander et al., 2006). They may be lower limits because we do not account for ventilation of MBL air containing $\mathrm{Br}_{\mathrm{y}}$ from sea-salt aerosol (Yang et al., 2005) or heterogeneous reactivation of $\mathrm{Br}_{\mathrm{y}}$ on aerosols (von Glasow et al., 2004; Yang et al., 2010).

Sea-salt aerosol bromide is an additional source of $\mathrm{Br}_{\mathrm{y}}$ for the MBL. Here we assume a uniform daytime concentration of $1 \mathrm{ppt} \mathrm{BrO}$, consistent with the few observations available (Leser et al., 2003; Saiz-Lopez et al., 2004; Martin et al., 2009; O'Brien et al., 2009) and with the observed diurnal cycle of RGM (Holmes et al., 2009). We calculate the associated $\mathrm{Br}$ concentrations from photochemical steady state (Platt and Janssen, 1995),

$$
\frac{[\mathrm{Br}]}{[\mathrm{BrO}]}=\frac{J_{\mathrm{BrO}}+k_{1}[\mathrm{NO}]}{k_{2}\left[\mathrm{O}_{3}\right]},
$$

where $J_{\mathrm{BrO}}$ is the $\mathrm{BrO}$ photolysis frequency, and $k_{1}=2.1 \times 10^{-11} \mathrm{~cm}^{3}$ molecule $^{-1} \mathrm{~s}^{-1}$ and $k_{2}=$ $1.2 \times 10^{-12} \mathrm{~cm}^{3}$ molecule ${ }^{-1} \mathrm{~s}^{-1}$ are the rate coefficients for the $\mathrm{BrO}+\mathrm{NO} \rightarrow \mathrm{Br}+\mathrm{NO}_{2}$ and $\mathrm{Br}+\mathrm{O}_{3} \rightarrow \mathrm{BrO}+\mathrm{O}_{2}$ reactions, respectively (Platt and Janssen, 1995). [NO] = $10 \mathrm{ppt}$ is assumed, and $\left[\mathrm{O}_{3}\right]$ and mean daytime $J_{\mathrm{BrO}}$ are archived from GEOS-Chem full-chemistry simulations (Park et al., 2004; Parrella et al., 2010). We impose a diurnal cycle for $\mathrm{Br}$ throughout the atmosphere as done by Holmes et al. (2009) and find that the global model reproduces the observed diurnal cycles of $\mathrm{Hg}^{\mathrm{II}}$ in the MBL as reported in that earlier study.

Springtime photochemistry of sea salt on sea ice can produce unusually high $\mathrm{Br}$ concentrations in the polar boundary layer in spring, resulting in fast oxidation of mercury and ozone (Simpson et al., 2007). BrO concentrations are typically 5-15 ppt (Steffen et al., 2008). Here we specify $10 \mathrm{ppt}$ $\mathrm{BrO}$ in the Arctic (Antarctic) boundary layer during MarchMay (August-October) over areas with sea ice, sunlight, stable conditions, and temperatures below $268 \mathrm{~K}$. We calculate the $\mathrm{Br}$ concentration in steady state as above, assuming that $\mathrm{O}_{3}$ is depleted to $2 \mathrm{ppb}$.

Figure 2 shows the resulting GEOS-Chem $\mathrm{Br}$ mixing ratios for the months of January and July. We also show BrO for reference although it does not oxidize $\mathrm{Hg}^{0}$ in the model. $\mathrm{Br}$ and $\mathrm{BrO}$ have a strong photochemically driven seasonal cycle in the extratropics. Concentrations increase with altitude due to photochemical production. Minima in the tropical lower troposphere reflect wet deposition of soluble inorganic bromine species. Br concentrations peak at the tropical tropopause due to strong radiation and relatively low ozone, but otherwise show little latitudinal variation in the summer hemisphere. Monthly mean $\mathrm{BrO}$ columns range from $1 \times 10^{13} \mathrm{~cm}^{-2}$ in the tropics to $4 \times 10^{13} \mathrm{~cm}^{-2}$ at the summer pole, which agrees well with values and latitudinal trends observed from satellites (Chance, 1998; Richter et al., 2002; Sioris et al., 2006), after we account for the two-fold difference between 24-h averages shown here and the daytime concentrations detected from space.

From these $\mathrm{Br}$ concentration fields and the mechanism in Table 1 we obtain a global $\mathrm{Hg}^{0}$ chemical lifetime of 6 months, with most of the oxidation taking place in the free troposphere. We find that $\mathrm{HgBrOH}$ is the major product, but it and other $\mathrm{Hg}^{\mathrm{II}}$ species are expected to undergo ion exchange in cloud and aerosol water to produce $\mathrm{HgCl}_{2}$ primarily (Hedgecock and Pirrone, 2001; Lin et al., 2006). 
Table 1. Gas-phase mercury-bromine reactions in GEOS-Chem.

\begin{tabular}{|c|c|c|}
\hline Reaction & Rate expression ${ }^{\mathrm{a}}$ & Reference $^{b}$ \\
\hline $\mathrm{Hg}^{0}+\mathrm{Br}+\mathrm{M} \rightarrow \mathrm{HgBr}+\mathrm{M}$ & $1.5 \times 10^{-32}(T / 298)^{-1.86}\left[\mathrm{Hg}^{0}\right][\mathrm{Br}][\mathrm{M}]$ & (1) \\
\hline $\mathrm{HgBr} \stackrel{\mathrm{M}}{\longrightarrow} \mathrm{Hg}^{0}+\mathrm{Br}$ & $3.9 \times 10^{9} \exp (-8357 / T)(T / 298)^{0.51}[\mathrm{HgBr}]$ & $\mathrm{c}$ \\
\hline $\mathrm{HgBr}+\mathrm{Br} \stackrel{\mathrm{M}}{\longrightarrow} \mathrm{HgBr}_{2}$ & $2.5 \times 10^{-10}(T / 298)^{-0.57}[\mathrm{HgBr}][\mathrm{Br}]$ & (2) \\
\hline $\mathrm{HgBr}+\mathrm{OH} \stackrel{\mathrm{M}}{\longrightarrow} \mathrm{HgBrOH}$ & $2.5 \times 10^{-10}(T / 298)^{-0.57}[\mathrm{HgBr}][\mathrm{OH}]$ & (2) \\
\hline $\mathrm{HgBr}+\mathrm{Br} \rightarrow \mathrm{Hg}^{0}+\mathrm{Br}_{2}$ & $3.9 \times 10^{-11}[\mathrm{HgBr}][\mathrm{Br}]$ & (3) \\
\hline
\end{tabular}

a Rate expressions have units of molecule $\mathrm{cm}^{-3} \mathrm{~s}^{-1}$. [ ] denotes concentration in units of molecules $\mathrm{cm}^{-3}$ and $[\mathrm{M}]$ is the number density of air. $T$ is temperature in $\mathrm{K}$.

b (1) Donohoue et al. (2006); (2) Goodsite et al. (2004); (3) Balabanov et al. (2005)

${ }^{c}$ Derived from the temperature-dependent reaction free energy $\left(\Delta G=56.5 \mathrm{~kJ} \mathrm{~mol}^{-1}\right.$ at $\left.298 \mathrm{~K}\right)$ for $\mathrm{Hg}^{0}+\mathrm{Br} \rightarrow \mathrm{HgBr}$ (Goodsite et al., 2004) and the above rate coefficient for the forward reaction.

A
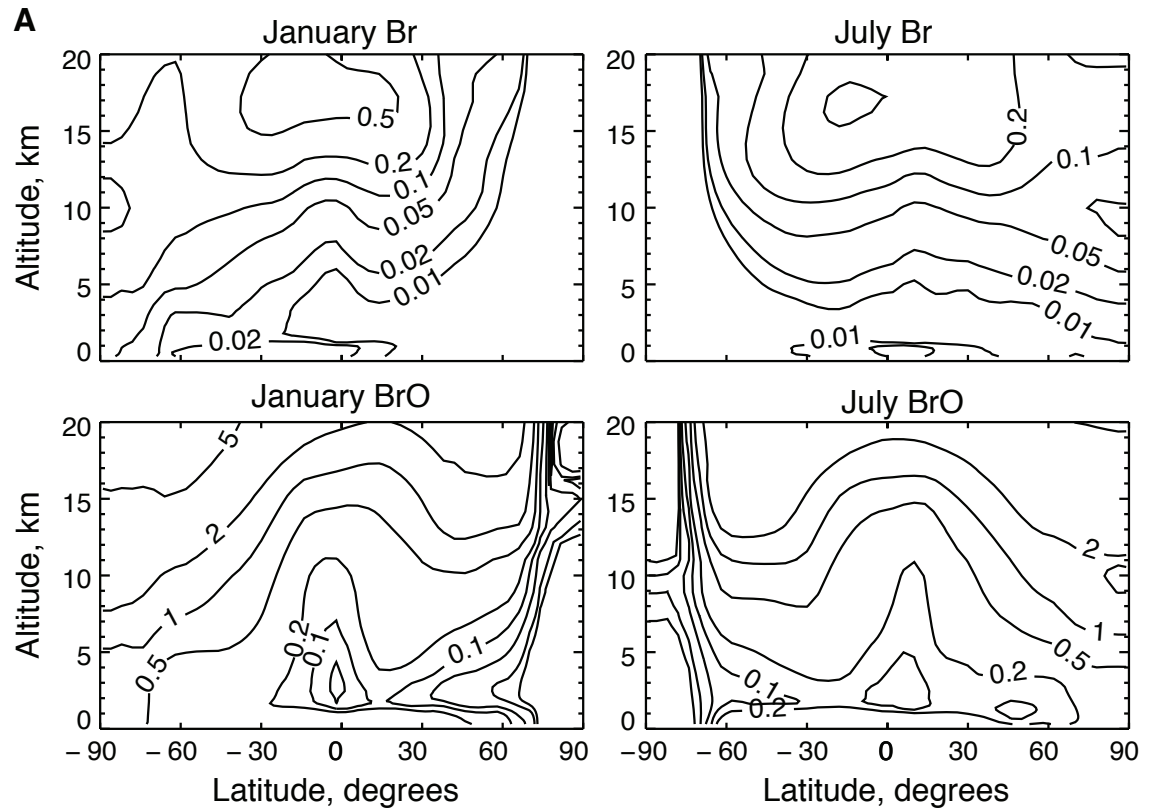

B

January column BrO
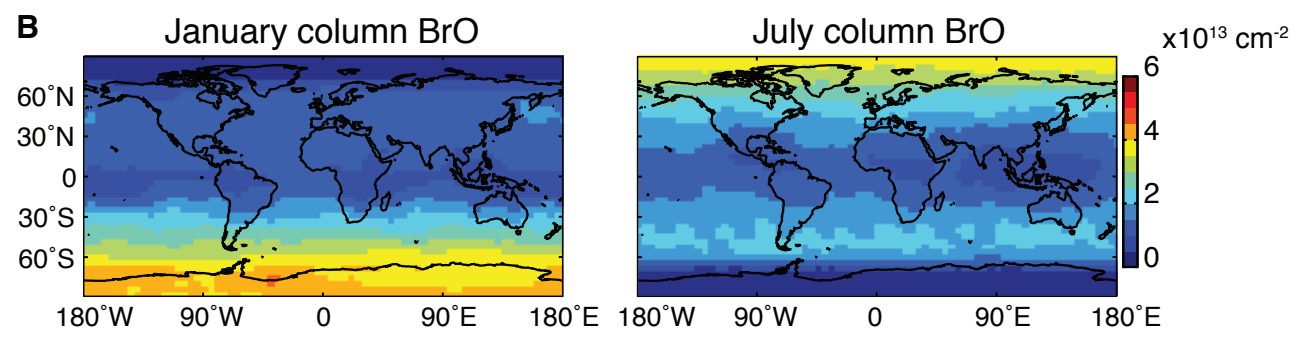

Fig. 2. (A) Zonal mean $\mathrm{Br}$ and $\mathrm{BrO}$ mixing ratios (ppt) and (B) BrO columns for January and July. Values are 24-h averages in GEOS-Chem.

Subsequent deposition of $\mathrm{Hg}^{\mathrm{II}}$ depends on its gas/aerosol partitioning, for which observations show considerable variability (Jaffe et al., 2005; Caldwell et al., 2006; Liu et al., 2007; Valente et al., 2007; Cobbett et al., 2007; WeissPenzias et al., 2009). This partitioning is expected to depend on temperature, aerosol load, and aerosol composition (Lin et al., 2006; Rutter and Schauer, 2007a,b). Future work will link $\mathrm{Hg}^{\mathrm{II}}$ partitioning to aerosol concentration and composi- tion in the model, while here we assume 50/50 partitioning of $\mathrm{Hg}^{\mathrm{II}}$ between the gas and aerosol phase for the purpose of calculating $\mathrm{Hg}^{\mathrm{II}}$ deposition as described in the following sub-sections.

Our initial simulation without reduction of $\mathrm{Hg}^{\mathrm{II}}$ produced mean $\mathrm{Hg}^{0}$ surface concentrations that were smaller than observed. Early global models for mercury included aqueous reduction of $\mathrm{Hg}^{\mathrm{II}}$ by $\mathrm{HO}_{2}$ and $\mathrm{SO}_{3}^{2-}$, but these reactions are 

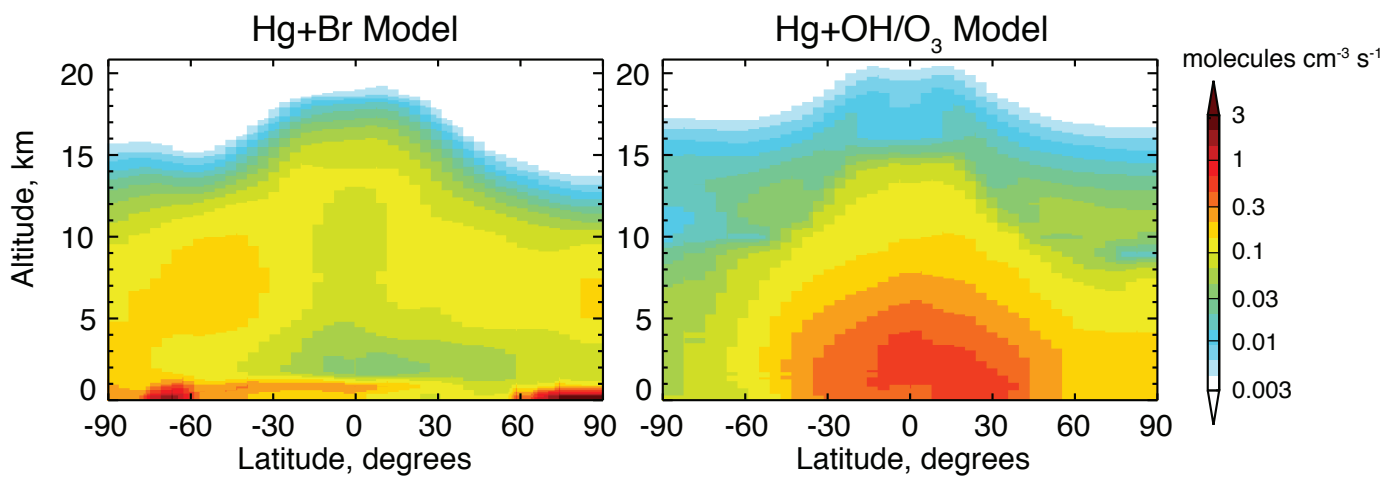

Fig. 3. Annual zonal-mean distribution of the $\mathrm{Hg}^{0}$ oxidation rate in GEOS-Chem under the $\mathrm{Hg}+\mathrm{Br}$ and $\mathrm{Hg}+\mathrm{OH} / \mathrm{O}_{3}$ chemical mechanisms.

now thought to be negligibly slow (Van Loon et al., 2000; Gårdfeldt and Jonsson, 2003). More recent models have hypothesized gaseous or aqueous reactions and tuned the kinetics to match the $\mathrm{Hg}^{0}$ observations (Selin et al., 2007; Pongprueksa et al., 2008). Laboratory studies have reported fast $\mathrm{UV}$ photoreduction of aqueous $\mathrm{HgCl}_{2}$ in the presence of organic acids (Pehkonen and Lin, 1998; Ababneh et al., 2006; $\mathrm{Si}$ and Ariya, 2008). We assume $\mathrm{Hg}^{\mathrm{II}}$ reduction in liquid water clouds to be proportional to the $\mathrm{NO}_{2}$ photolysis frequency, archived from a GEOS-Chem full-chemistry simulation (J. Mao et al., 2010), and adjust the reduction rate to best match the global mean surface $\mathrm{Hg}^{0}$ measurements. The best fit yields a $\mathrm{Hg}^{\mathrm{II}}$ global tropospheric lifetime of 1.7 months against reduction. After including reduction, the mean atmospheric lifetime of mercury is 7.3 months $(6.5$ months in the troposphere). We will also discuss results from a sensitivity simulation without $\mathrm{Hg}^{\mathrm{II}}$ reduction and instead decreasing the overall rate of $\mathrm{Hg}^{0}+\mathrm{Br}+\mathrm{X} \rightarrow \rightarrow \mathrm{Hg}^{\mathrm{II}}(\mathrm{X} \equiv \mathrm{Br}, \mathrm{OH})$ reaction by $60 \%$ to yield the same atmospheric lifetime of mercury as in the standard simulation. This decrease in oxidation lies within the range of theory-derived kinetic coefficients for $\mathrm{HgBr}+\mathrm{X} \rightarrow \mathrm{HgBrX}$ (Goodsite et al., 2004; Balabanov et al., 2005) or could be accommodated by lower atomic $\mathrm{Br}$ concentrations.

An important objective of this study is to evaluate the ability of GEOS-Chem to fit observations using $\mathrm{Br}$ as the sole $\mathrm{Hg}^{0}$ oxidant instead of $\mathrm{OH}$ and ozone. We will compare results from a simulation with $\mathrm{Br}$ chemistry (the " $\mathrm{Hg}+\mathrm{Br}$ model") versus one with $\mathrm{OH}$ and ozone chemistry (" $\mathrm{Hg}+\mathrm{OH} / \mathrm{O}_{3}$ model"). While both oxidation mechanisms, and possibly others, may operate together in the real atmosphere, these idealized simulations enable us to explore the constraints that observations place on the atmospheric chemistry of mercury. For the $\mathrm{Hg}+\mathrm{OH} / \mathrm{O}_{3}$ model we follow the kinetics of Sommar et al. (2001) and Hall (1995), as used by Selin et al. (2007), with $\mathrm{OH}$ and ozone concentrations specified from a full-chemistry GEOS-Chem simulation. The resulting oxidation of $\mathrm{Hg}^{0}$ is faster than by $\mathrm{Br}$ and takes place at lower altitudes where $\mathrm{Hg}^{\mathrm{II}}$ deposits faster, so we com- pensate by increasing the reduction rate coefficient 4 fold. The $\mathrm{Hg}^{0}$ lifetime in that simulation is 3.7 months with $\mathrm{OH}$ contributing $80 \%$ of the sink, but with the faster reduction the atmospheric lifetime of total mercury is the same as in the $\mathrm{Hg}+\mathrm{Br}$ model. Figure 3 shows the zonal distribution of $\mathrm{Hg}^{0}$ oxidation in the $\mathrm{Hg}+\mathrm{Br}$ and $\mathrm{Hg}+\mathrm{OH} / \mathrm{O}_{3}$ models. Oxidation by bromine is fast in the MBL where $\mathrm{Br}$ number density is largest, but most of the global oxidation occurs in the free troposphere due to low temperatures and increasing $\mathrm{Br}$ mixing ratios with altitude (Holmes et al., 2006). Oxidation is also fast in the stratosphere but limited by the small concentrations of $\mathrm{Hg}^{0}$. The Southern Hemisphere has faster oxidation than the Northern Hemisphere because of the oceanic source of bromocarbons and the low temperatures over Antarctica. Springtime bromine explosions drive secondary oxidation maxima in the polar boundary layers. Oxidation by $\mathrm{OH}$ and $\mathrm{O}_{3}$ follows the general distribution of $\mathrm{OH}$ concentrations, with a maximum in the lower tropical troposphere and symmetry about the equator. Reduction of $\mathrm{Hg}^{\mathrm{II}}$ (not shown) peaks at 1-2 km altitude, where cloud liquid water is high, and no reduction occurs above $10 \mathrm{~km}$ where clouds are entirely ice.

\subsection{Sea-salt aerosol as a sink for mercury}

Building on earlier work by Hedgecock and Pirrone (2001) and Selin et al. (2007), we previously suggested that uptake of $\mathrm{Hg}^{\mathrm{II}}$ by sea-salt aerosol as $\mathrm{HgCl}_{4}^{2-}$ is the dominant sink for $\mathrm{Hg}^{\mathrm{II}}$ in the MBL and the major source of mercury to the surface ocean (Holmes et al., 2009). We calculated the $\mathrm{Hg}^{\mathrm{II}}$ uptake rate and subsequent deposition flux $\left(F_{\text {dep }}\right)$ in a box model of the MBL on the basis of the local 10-m wind speed $\left(u_{10}\right)$, relative humidity (saturation ratio $S$ ) and mixing depth $(H)$. Fast winds enhance uptake through increased sea spray, while low relative humidity increases $\left[\mathrm{Cl}^{-}\right]$within the seasalt particles and hence promotes formation of $\mathrm{HgCl}_{4}^{2-}$. We accounted for mass-transport limitations at the gas-particle interface over the sea-salt aerosol size distribution. Here we parameterize the results from this MBL box model for 


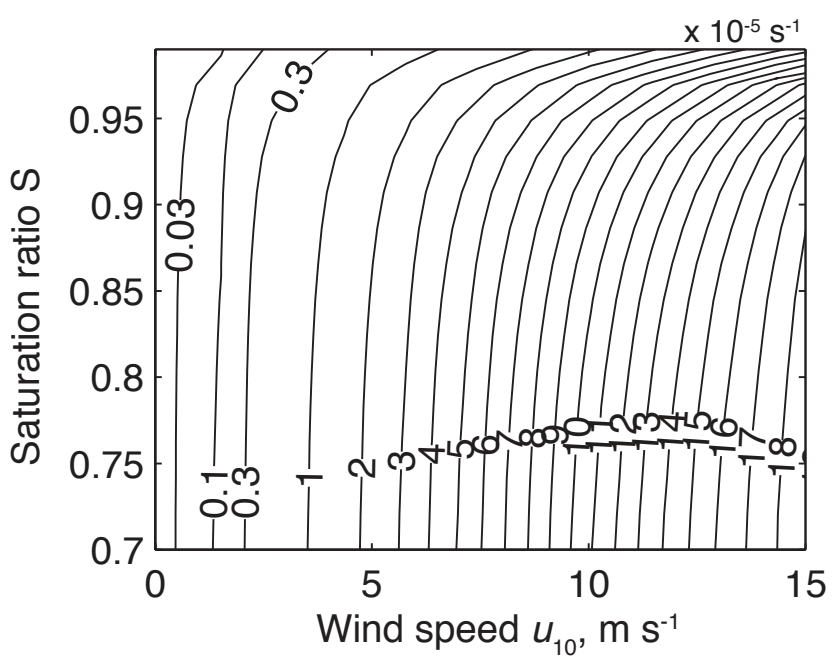

Fig. 4. Rate coefficient $k,\left(10^{-5} \mathrm{~s}^{-1}\right)$ for gaseous $\mathrm{Hg}^{\mathrm{II}}$ uptake and deposition by sea-salt aerosol as simulated by the marine boundary layer model of Holmes et al. (2009) as a function of 10-m wind speed $\left(u_{10}\right)$ and water vapor saturation ratio $(S)$. For each $\left(u_{10}, S\right)$ pair we conducted 40 Monte Carlo simulations with other box model parameters varying over their likely ranges.

implementation in GEOS-Chem as a first-order rate coefficient $(k)$ for $\mathrm{Hg}^{\mathrm{II}}$ net uptake and subsequent deposition,

$F_{\text {dep }}=k\left(u_{10}, S\right) H\left[\mathrm{Hg}^{\mathrm{II}}\right]$,

where $\left[\mathrm{Hg}^{\mathrm{II}}\right]$ is the MBL concentration. Figure 4 shows $k\left(u_{10}, S\right)$ simulated in the box model with full physics over the range of conditions expected in the marine atmosphere (Holmes et al., 2009). We fit $k$ to the following form:

$$
\begin{aligned}
k\left(u_{10}, S\right)= & a_{0}\left[1-\exp \left(a_{1}(1-S)\right)\right] \\
& \exp \left(a_{2} u_{10}+a_{3} u_{10}^{1 / 2}+a_{4} u_{10}^{3 / 2}\right)
\end{aligned}
$$

with coefficients $a_{0}=1 \times 10^{-10} \mathrm{~s}^{-1}, \quad a_{1}=-59.91$, $a_{2}=-1.935 \mathrm{~s} \mathrm{~m}^{-1}, \quad a_{3}=9.009 \mathrm{~s}^{1 / 2} \mathrm{~m}^{-1 / 2}, \quad$ and $a_{4}=0.1477 \mathrm{~s}^{3 / 2} \mathrm{~m}^{-3 / 2}$. This simplified model closely fits the 24-h mean loss rate in the full-physics model $\left(r^{2}=0.97\right)$ over the parameter range $0.7 \leq S \leq 0.99$ and $0.1 \leq u_{10} \leq 20 \mathrm{~m} \mathrm{~s}^{-1}$.

\subsection{Other deposition processes}

GEOS-Chem includes wet scavenging of $\mathrm{Hg}^{\mathrm{II}}$ and $\mathrm{Hg}_{P}$ following the scheme of Liu et al. (2001), and dry deposition of $\mathrm{Hg}^{0}, \mathrm{Hg}^{\mathrm{II}}$, and $\mathrm{Hg}_{\mathrm{P}}$ following the resistance-in-series scheme of Wesely (1989). Selin and Jacob (2008) describe how these schemes apply to mercury in the previous version of the model. They assumed $\mathrm{Hg}^{\mathrm{II}}$ to be gaseous $\mathrm{HgCl}_{2}$ for the purpose of computing deposition; the Henry's law solubility constant of $\mathrm{HgCl}_{2}$ is $1.4 \times 10^{6} \mathrm{M} \mathrm{atm}^{-1}$ (Lindqvist and Rodhe, 1985), sufficiently high for near- $100 \%$ scavenging in clouds and fast dry deposition limited by aerodynamic resistance. Here we assume 50/50 partitioning of $\mathrm{Hg}^{\mathrm{II}}$ between the gas and aerosol phase, which increases the lifetime of $\mathrm{Hg}^{\mathrm{II}}$ against dry deposition as compared to the previous model version.

Selin and Jacob (2008) assumed no scavenging of $\mathrm{Hg}^{\mathrm{II}}$ in cold (frozen) clouds and snow, and zero retention efficiency of $\mathrm{Hg}^{\mathrm{II}}$ upon cloud freezing, in order to reproduce the observations of low wet deposition fluxes of mercury at northern US sites in winter. However, observations by Douglas et al. (2008) indicate high mercury concentrations in rime ice, implying high retention efficiency. Therefore we now assume that supercooled water in mixed-phase clouds retains all $\mathrm{Hg}^{\mathrm{II}}$ and $\mathrm{Hg}_{\mathrm{P}}$ during freezing. Douglas et al. (2008) and Johnson et al. (2008) found by contrast very low Hg concentrations in ice grown from the vapor phase, so we still assume no mercury scavenging by cloud ice. Below-cloud scavenging by snow is included only for aerosol $\mathrm{Hg}^{\mathrm{II}}$ and $\mathrm{Hg}_{\mathrm{P}}$, with the same efficiency as by rain (Murakami et al., 1983; Feng, 2009). Sigler et al. (2009) found that snowfall has little effect on ambient RGM, so we do not include below-cloud scavenging of gaseous $\mathrm{Hg}^{\mathrm{II}}$ by snow. Adding low-temperature scavenging as described above increases deposition at high latitudes, but also allows low-latitude convective rainfall to scavenge from higher altitudes.

\section{Model evaluation}

We test here whether the $\mathrm{Hg}+\mathrm{Br}$ model (simulation with $\mathrm{Hg}^{0}$ oxidation initiated by $\mathrm{Br}$ only) can reproduce the general patterns seen in atmospheric observations, and compare these results to the $\mathrm{Hg}+\mathrm{OH} / \mathrm{O}_{3}$ model (simulation with $\mathrm{Hg}^{0}$ oxidation by $\mathrm{OH}$ and $\mathrm{O}_{3}$ ). All simulations are initialized over 15 years of repeated present-day meteorological data to reach annual steady state in the stratosphere. We then analyze model results averaged over 2006-2008 and compare to observed air concentrations and wet deposition fluxes.

\subsection{Global distribution of mercury}

Figure 5 shows annual mean observed surface concentrations of total gaseous mercury ( $\mathrm{TGM} \equiv \mathrm{Hg}^{0}+\mathrm{RGM}$ ) compared to the $\mathrm{Hg}+\mathrm{Br}$ model. TGM in the model is calculated as $\mathrm{Hg}^{0}+0.5 \mathrm{Hg}^{\mathrm{II}}$. The measurements include annual means at 39 land sites during 2000-2008, plus data from ship cruises (Lamborg et al., 1999; Laurier et al., 2003; Temme et al., 2003; Laurier and Mason, 2007; Soerensen et al., 2010a). Trends in mean TGM during the last decade are small (of order $1 \% \mathrm{a}^{-1}$ ) or negligible at most background sites in the Northern Hemisphere (Temme et al., 2007; Wangberg et al., 2007). Southern Hemisphere data contain larger trends (Slemr et al., 2010) which we discuss below. The model reproduces the spatial variability observed at at the 39 land sites $\left(r^{2}=0.81\right)$. The mean and 


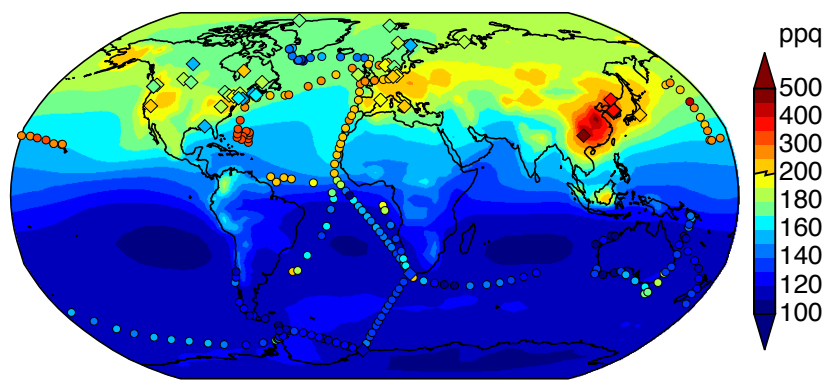

Fig. 5. Global distribution of total gaseous mercury (TGM) concentrations in surface air $\left(1 \mathrm{ppq}=10^{-15} \mathrm{~mol} \mathrm{~mol}^{-1}=8.97 \mathrm{pg} \mathrm{m}^{-3}\right.$ at $273 \mathrm{~K}, 1013 \mathrm{hPa}$ ). Model values (background) are annual means for 2006-2008. Data for land sites (diamonds) are annual means for available years during 2000-2008 and all other observations from ship cruises (circles) are averaged over $1^{\circ}$ latitude bins. Observations include those used by Selin et al. (2007), plus additional sites in Europe (Steffen et al., 2005, EMEP 2009), North America (Steffen et al., 2005; Yatavelli et al., 2006; Stamenkovic et al., 2007; Temme et al., 2007; Choi et al., 2008; Sigler et al., 2009, E. Edgerton, personal communication, 2008), East Asia (Nguyen et al., 2007; Sakata and Asakura, 2007; Feng et al., 2008; Wan et al., 2009), South Africa (Slemr et al., 2010) and the Galathea cruise (Soerensen et al., 2010a). Note the change in linear color scale at 200 ppq.

standard deviation for the ensemble of sites is $209 \pm 112 \mathrm{ppq}$ $\left(1 \mathrm{ppq}=10^{-15} \mathrm{~mol} \mathrm{~mol}^{-1}=8.97 \mathrm{pg} \mathrm{m}^{-3}\right.$ at $\left.273 \mathrm{~K}, 1013 \mathrm{hPa}\right)$ in the observations and $191 \pm 59 \mathrm{ppq}$ in the model. The model is unbiased with respect to sites in Europe and North America. The $\mathrm{Hg}+\mathrm{OH} / \mathrm{O}_{3}$ model matches observations similarly well (189 $\left.\pm 56 \mathrm{ppq}, r^{2}=0.80\right)$ because anthropogenic emissions strongly influence the variability of TGM concentrations at the land sites.

A prominent deficiency in the model, previously identified by Selin et al. (2007), is that it does not reproduce the high concentrations observed over the North Atlantic and Pacific Oceans during ship cruises. This is likely due to upwelling mercury from the sub-surface ocean, possibly reflecting the legacy of past anthropogenic emissions. Although this is not captured in our simulation, where uniform sub-surface ocean mercury concentrations are assumed globally (Strode et al., 2007), Soerensen et al. (2010b) find that forcing GEOSChem with observed sub-surface North Atlantic concentrations can reproduce the high atmospheric concentrations observed over the North Atlantic. This will be implemented in a future version of the model.

Figure 6 shows that the $\mathrm{Hg}+\mathrm{Br}$ and $\mathrm{Hg}+\mathrm{OH} / \mathrm{O}_{3}$ models diverge in their surface TGM predictions for the Southern Hemisphere because of the different oxidant distributions (Figs. 2 and 3). The $\mathrm{Hg}+\mathrm{Br}$ model predicts 110 $120 \mathrm{ppq}$ TGM at southern mid-latitudes vs. 140-150 ppq in the $\mathrm{Hg}+\mathrm{OH} / \mathrm{O}_{3}$ model. The $\mathrm{Hg}+\mathrm{Br}$ model better simulates land stations in Antarctica (Temme et al., 2003) and

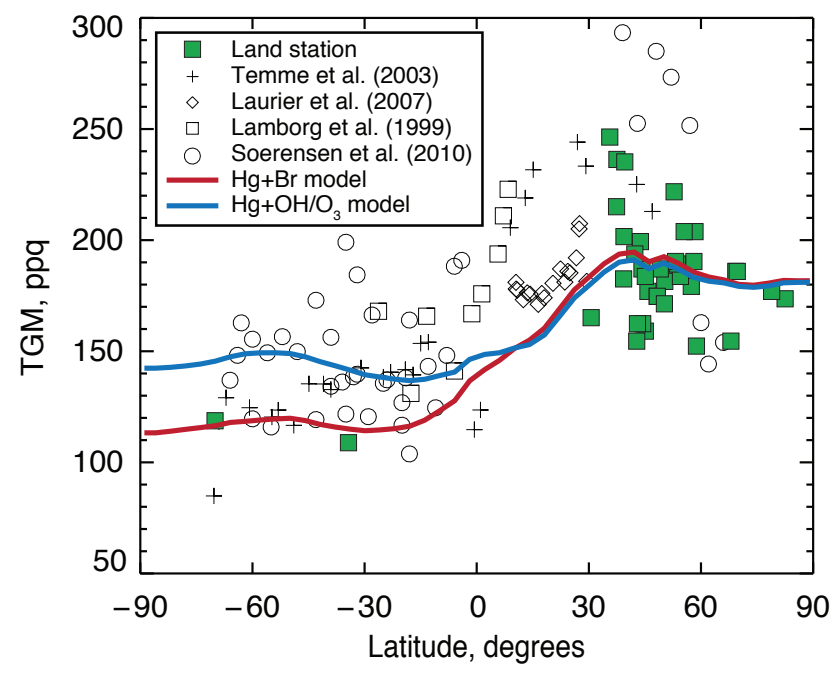

Fig. 6. Meridional gradient of total gaseous mercury (TGM). The model is averaged zonally during 2006-2008. Observations are the same as in Fig. 5.

Cape Point, South Africa (F. Slemr, unpublished post-2008 data). However the trend at Cape Point from $135 \mathrm{ppq}$ during 2000-2004 to 105 ppq after 2008 (Slemr et al., 2010) spans the range between the $\mathrm{Hg}+\mathrm{Br}$ and $\mathrm{Hg}+\mathrm{OH} / \mathrm{O}_{3}$ models. Ship data at southern mid-latitudes likewise encompass a wide range (110-160 ppq), likely caused by variability in marine emissions, that does not discriminate between the two simulations. Additional long-term measurements at a southern mid-latitude site, complementing the record at Cape Point, together with greater constraints on Southern Hemisphere ocean emissions would further test the $\mathrm{Hg}^{0}$ oxidation mechanism.

The meridional gradient in Fig. 6 differs markedly from the model of Seigneur and Lohman (2008), which predicted peak $\mathrm{Hg}^{0}$ in the tropics and unrealistically low concentrations in the extra-tropics when $\mathrm{Br}$ was the sole oxidant. Seigneur and Lohman inferred $\mathrm{Br}$ concentrations from the GOME BrO columns, imposing vertical distributions and $\mathrm{Br} / \mathrm{BrO}$ ratios from the p-TOMCAT CTM (Yang et al., 2005). That CTM does not include halons and would therefore greatly underestimate the contribution of the stratosphere to the BrO column. Considering that the stratospheric contribution is what causes the $\mathrm{BrO}$ column increase with latitude (Fig. 2), this method would particularly overestimate tropospheric $\mathrm{Br}$ and, hence, $\mathrm{Hg}^{0}$ oxidation at high latitudes.

\subsection{Seasonal cycle at surface sites}

Figure 7 compares simulated and observed seasonal cycles of TGM at surface sites. Northern mid-latitude sites show on average a late summer minimum in both observations and the model. Bergan and Rodhe (2001) and Selin et al. (2007) 

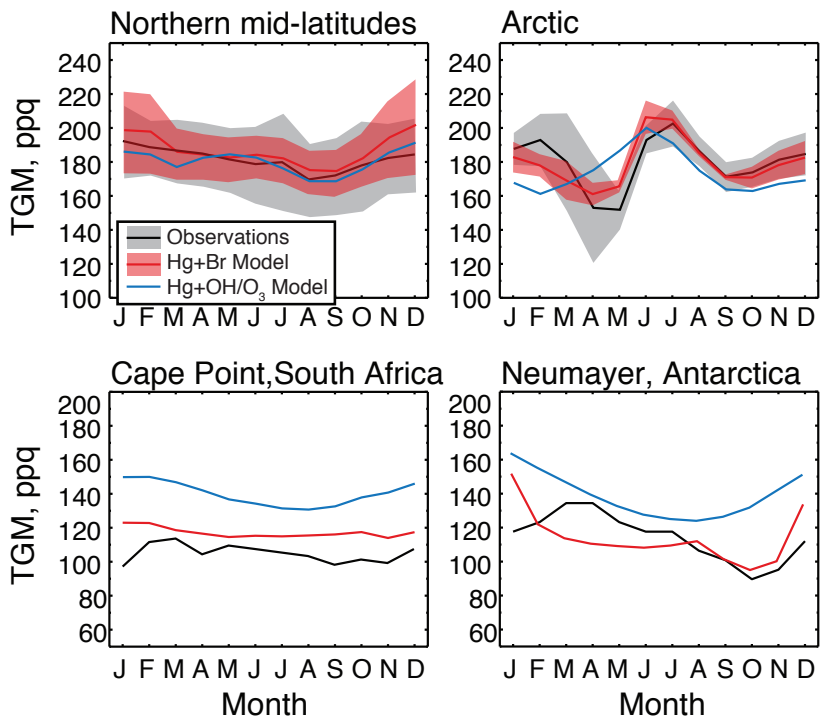

Neumayer, Antarctica

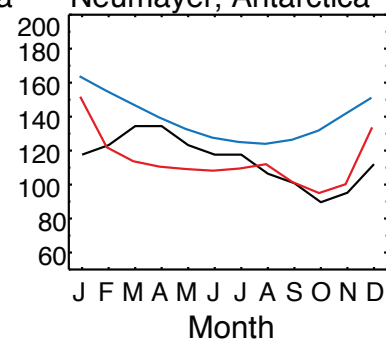

Fig. 7. Mean seasonal variation of total gaseous mercury (TGM) at Arctic, northern mid-latitude, and Southern Hemisphere sites. The northern mid-latitude panel shows an average over 15 sites where monthly mean data are available, including the sites from Selin et al. (2007) plus Andoya and Birkenes, Norway (EMEP 2009); Kuujjuarapik, Canada (Steffen et al., 2005); Athens, Ohio; and Pensacola, Florida in the US (Yatavelli et al., 2006, E. Edgerton, personal communication, 2008). Cape Point data are means for 20072008 (F. Slemr, unpublished data). The Arctic panel is an average over 3 sites: Alert, Canada; Zeppelin, Norway; and Amderma, Russia (Steffen et al., 2005, EMEP 2009). Shaded areas show standard deviation among sites for observations and for the $\mathrm{Hg}+\mathrm{Br}$ model.

attributed this seasonal cycle to the photochemical sink from $\mathrm{OH}$, and we obtain the same result with oxidation by $\mathrm{Br}$ which also peaks in summer.

At Cape Point, the only site with long-term data in the Southern Hemisphere outside Antarctica, TGM displays little seasonal variation during recent years, as shown. Before 2004, however, TGM had larger variation with TGM maxima in summer (December-February), in contrast to the Northern Hemisphere (Slemr et al., 2008). The $\mathrm{Hg}+\mathrm{OH} / \mathrm{O}_{3}$ model reproduces the earlier pattern, which reflects the maximum of ocean emissions in austral summer caused by biological and photochemical reduction of aqueous $\mathrm{Hg}^{\mathrm{II}}$ (Strode et al., 2007; Slemr et al., 2008). The $\mathrm{Hg}+\mathrm{Br}$ model has smaller seasonal variation due to the offsetting effect of strong oxidation by $\mathrm{Br}$ at southern mid-latitudes in summer and this coincides with the recent seasonal data. This reinforces the value of additional measurements of mercury concentration and interannual variability of ocean fluxes in Southern Hemisphere.
Observations at Arctic sites and at the Neumayer Antarctic site show a springtime minimum driven by MDEs and a summertime maximum driven by re-emission from the snowpack (Steffen et al., 2005; Cobbett et al., 2007). The $\mathrm{Hg}+\mathrm{Br}$ model can reproduce this seasonal variation but not the $\mathrm{Hg}+\mathrm{OH} / \mathrm{O}_{3}$ model, which does not include MDEs. We find that atmospheric concentrations are consistent with reemission of $60 \%$ of $\mathrm{Hg}$ deposited to the snowpack during springtime and $40 \%$ net incorporation into the ocean and soil. The area within the Arctic Circle receives $60 \mathrm{Mg} \mathrm{a}^{-1}$ net deposition in the $\mathrm{Hg}+\mathrm{Br}$ model vs. $40 \mathrm{Mg} \mathrm{a}^{-1}$ in the $\mathrm{Hg}+\mathrm{OH} / \mathrm{O}_{3}$ model without MDEs. The Antarctic Circle similarly receives $70 \mathrm{Mg} \mathrm{a}^{-1}$ in the $\mathrm{Hg}+\mathrm{Br}$ model, but only $20 \mathrm{Mg} \mathrm{a}^{-1}$ in the $\mathrm{Hg}+\mathrm{OH} / \mathrm{O}_{3}$ model. Dastoor et al. (2008) estimate a similar re-emission fraction from snow, but 3 times larger net deposition to the Arctic surface.

\subsection{Testing oxidation chemistry through Antarctic subsidence events}

Observations at Antarctic sites show frequent summertime events of depleted $\mathrm{Hg}^{0}$ and enhanced RGM together with elevated ozone (Sprovieri et al., 2002; Temme et al., 2003; Aspmo and Berg, 2009). These differ from springtime depletion events in that $\mathrm{O}_{3}$ is anti-correlated with $\mathrm{Hg}^{0}$. From four events in the published Neumayer and Terra Nova Bay data (Sprovieri et al., 2002; Temme et al., 2003), we estimate ranges of -6.0 to -11.5 for $\Delta \mathrm{Hg}^{0} / \Delta \mathrm{O}_{3}$ and 1.5 to 4.0 for $\Delta \mathrm{RGM} / \Delta \mathrm{O}_{3}$. Aspmo and Berg (2009) used backtrajectories to identify the mid-troposphere as the source region for such events. Brooks et al. (2008) also found that subsiding air at the South Pole contains elevated $\mathrm{Hg}^{\mathrm{II}}$. These observations provide a sensitive test for $\mathrm{Hg}^{0}$ oxidation chemistry in the model because the cold, dry Antarctic atmosphere minimizes the confounding effect of aqueous reduction. In addition, $\mathrm{Br}$ is an effective $\mathrm{Hg}^{0}$ oxidant over Antarctica in summer (Fig. 3) while $\mathrm{OH}$ is ineffective.

Figure 8 shows simulated $\mathrm{Hg}^{0}$ and RGM at Neumayer for January 2008, and $\mathrm{O}_{3}$ from a GEOS-Chem full-chemistry simulation at the same time and location (J. Mao et al., 2010). The model time series shows several subsidence events with enhanced $\mathrm{O}_{3}$ and RGM, and depleted $\mathrm{Hg}^{0}$. These events last 1-3 days, as found by Temme et al. (2003). We derive the model $\Delta \mathrm{Hg}^{0} / \Delta \mathrm{O}_{3}$ and $\Delta \mathrm{RGM} / \Delta \mathrm{O}_{3}$ ratios shown in Fig. $8 \mathrm{~B}$ from a reduced major-axis fit to the January time series. The ratios in the $\mathrm{Hg}+\mathrm{Br}$ model are consistent with observations while those in the $\mathrm{Hg}+\mathrm{OH} / \mathrm{O}_{3}$ model are much too weak.

\subsection{Wet deposition}

Figure 9 compares the $\mathrm{Hg}+\mathrm{Br}$ model with annual wet deposition measurements from the Mercury Deposition Network (MDN, National Atmospheric Deposition Program, 2009) over North America and the European Monitoring and 
A

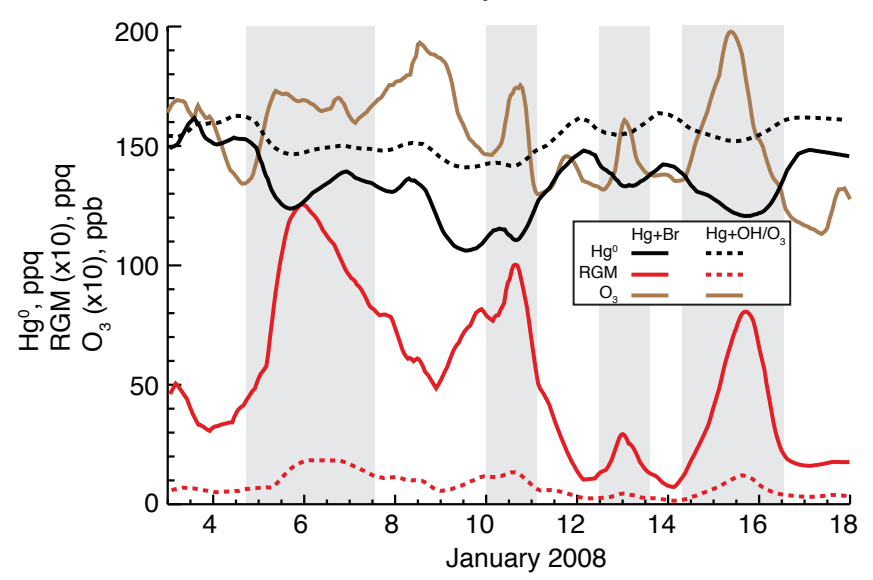

B

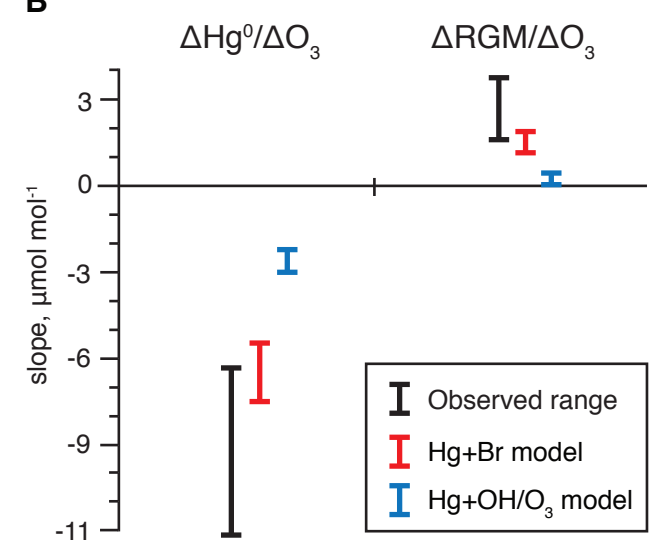

Fig. 8. (A) Time series of $\mathrm{Hg}^{0}$, $\mathrm{RGM}$ and $\mathrm{O}_{3}$ simulated at Neumayer, Antarctica in the $\mathrm{Hg}+\mathrm{Br}$ and $\mathrm{Hg}+\mathrm{OH} / \mathrm{O}_{3}$ models. Shaded regions show summertime subsidence events diagnosed with relative humidity and $\mathrm{O}_{3}$ data. (B) $\Delta \mathrm{Hg}^{0} / \Delta \mathrm{O}_{3}$ and $\Delta \mathrm{RGM} / \Delta \mathrm{O}_{3}$ ratios during January-February. Observed ratios were calculated from data reported by Temme et al. (2003). Modeled ranges are $95 \%$ confidence intervals for the reduced major-axis slope from the bootstrap method.
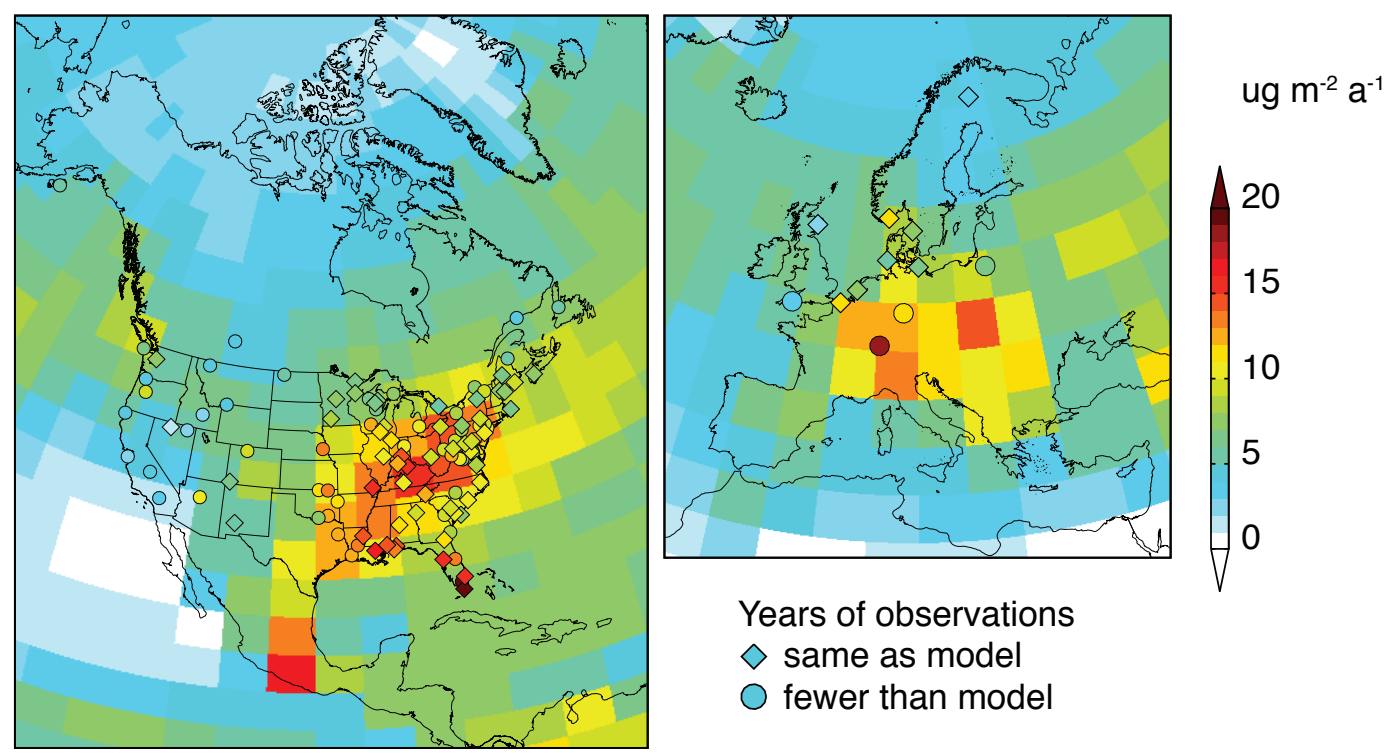

Fig. 9. Annual mercury wet deposition over North America during 2006-2008 and Europe during 2006-2007 from the Hg $+\mathrm{Br}$ model. Overlaid points show observations for the same years from the Mercury Deposition Network (MDN) over North America and from the European Monitoring and Evaluation Programme (EMEP) over Europe.

Evaluation Programme (EMEP) over Europe. These networks collect weekly (MDN) or monthly (EMEP) integrated samples. We use sites with at least $75 \%$ of annual data available for the simulated years, 2006-2008. We also require fewer than 5 consecutive missing samples for MDN. Both MDN and EMEP have been used extensively to test atmospheric mercury models (e.g. Selin and Jacob, 2008; Bullock et al., 2009; Gusev et al., 2009) and to evaluate the impact of mercury emission reductions (e.g. Butler et al., 2008; Wangberg et al., 2007; Pacyna et al., 2009; Prestbo and Gay, 2009).
Wet deposition is very similar in the $\mathrm{Hg}+\mathrm{OH} / \mathrm{O}_{3}$ model except where discussed below.

The model predicts the highest wet deposition in the coalburning regions of Europe and North America, reflecting near-field deposition of $\mathrm{Hg}^{\mathrm{II}}$ and $\mathrm{Hg}_{\mathrm{P}}$ emissions. Observations over Europe are elevated in the industrialized central region and show a poleward decrease in deposition with similar magnitude to the model. Over the Eastern US, the observations likewise show high deposition stretching from Texas to the Mid-Atlantic states, where anthropogenic 
mercury emissions are largest. At the northern end of this band the model exceeds observations, regardless of oxidant.

Figure 10 shows the seasonal cycle of wet deposition in the Eastern US and reveals that the positive model bias in the Northeast occurs mainly in winter. Suppressing cold scavenging can eliminate the bias, as found by Selin and Jacob (2008), but observations indicate that such scavenging occurs (Douglas et al., 2008), and suppressing cold scavenging in the model would cause $40 \%$ underestimates of deposition in Alaska, Alberta and Finland. Fast reduction may compete with near-field deposition for the fate of $\mathrm{Hg}^{\mathrm{II}}$ emissions. We assume in the model that reduction is photochemical and therefore ineffective in winter, but it is possible that reduction occurs in all seasons or, equivalently, that the fraction of mercury emitted as $\mathrm{Hg}^{\mathrm{II}}$ is too high in current inventories (Edgerton et al., 2006; Pongprueksa et al., 2008). This would decrease wet deposition over the Mid-Atlantic and Midwest emission regions (Lohman et al., 2006; Vijayaraghavan et al., 2008).

Sites around the Gulf of Mexico report the highest mercury wet deposition in North America, even though regional mercury emissions are lower than in the Northeast US. Convective scavenging of mercury from the free troposphere likely causes this regional feature (Guentzel et al., 2001; Selin and Jacob, 2008). The $\mathrm{Hg}+\mathrm{Br}$ model underpredicts wet deposition here by $50 \%$. While the $\mathrm{Hg}+\mathrm{OH} / \mathrm{O}_{3}$ model is closer to observations in the northern Gulf region, it is still 40\% lower than MDN sites in southern Florida. On a monthly basis, both models overlap the observed wet deposition range in the Gulf region during November-May, as seen in Fig. 10, but only the $\mathrm{Hg}+\mathrm{OH} / \mathrm{O}_{3}$ model has a strong deposition peak during the wet summer months, which accounts for its better comparison with the annual mean. During these months $\mathrm{OH}$ provides a vigorous subtropical $\mathrm{Hg}^{\mathrm{II}}$ source available for convective scavenging in the $\mathrm{Hg}+\mathrm{OH} / \mathrm{O}_{3}$ model, while there is little $\mathrm{Br}$ present in the $\mathrm{Hg}+\mathrm{Br}$ model. $\mathrm{Br}$ concentrations could be larger than are specified here if ventilation of sea-salt-derived $\mathrm{Br}_{\mathrm{y}}$ from the MBL or heterogeneous reactivation of $\mathrm{Br}_{\mathrm{y}}$ are important (see Sect. 2.2).

\subsection{Aircraft measurements}

Figure 11 shows mean vertical profiles measured from aircraft during the INTEX-B and ARCTAS campaigns over North America and the Pacific and Arctic Oceans (Talbot et al., 2007, 2008; H. Mao et al., 2010), plus CARIBIC flights over the Atlantic Ocean, Eurasia and North America (Ebinghaus et al., 2007; Slemr et al., 2009). Due to uncertain inlet loss of RGM, the measurements include $\mathrm{Hg}^{0}$ plus some fraction of gaseous $\mathrm{Hg}^{\mathrm{II}}$. This provides an upper limit for $\mathrm{Hg}^{0}$ and a lower limit for TGM, and we refer to it here as $\mathrm{Hg}^{0 *}$. We increase the INTEX-B measurements by $40 \%$ based on an in-flight intercomparison (Swartzendruber et al., 2008). The aircraft data are still $\sim 10 \%$ lower on average than the

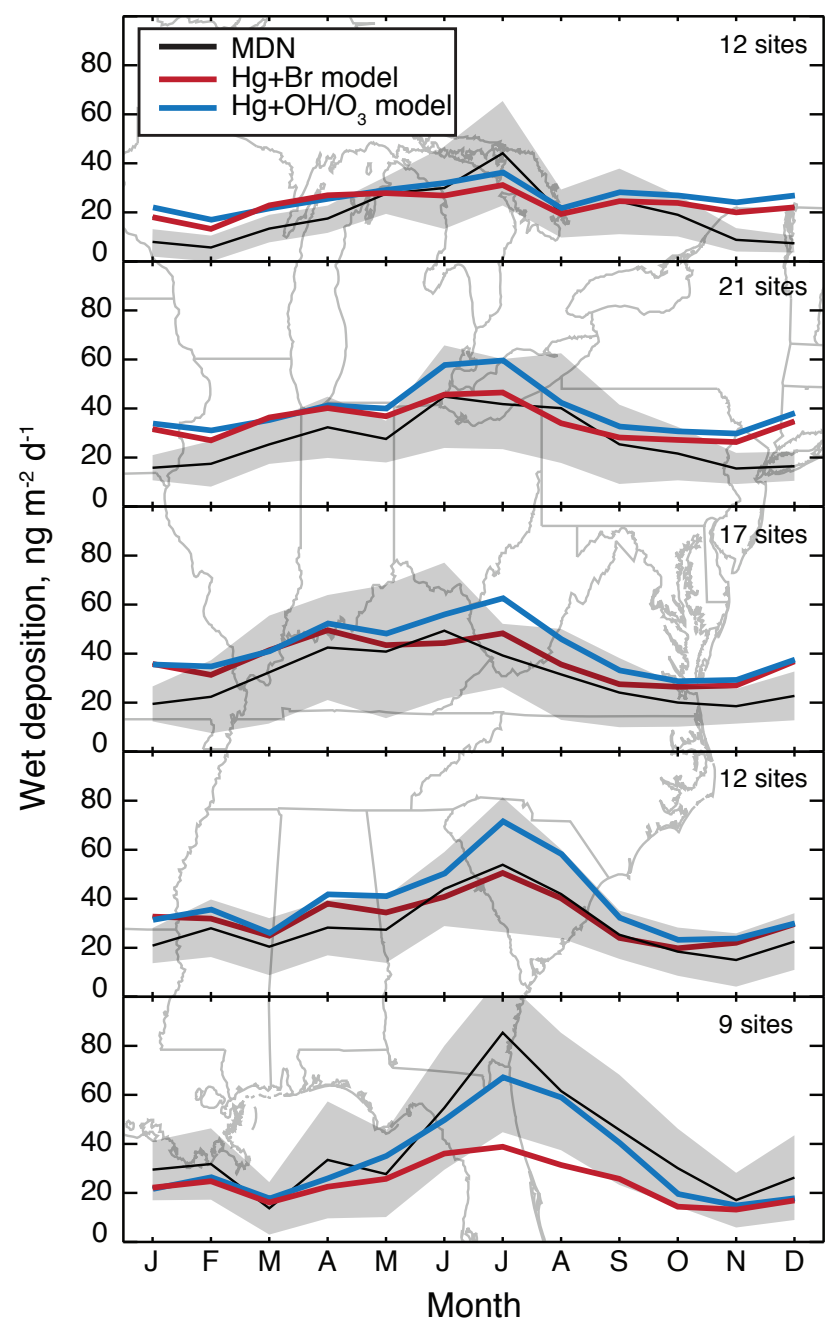

Fig. 10. Mean seasonal variation of mercury wet deposition to the Eastern United States for 2006-2008. Observations include all MDN sites within each depicted region with more than 21 days of data per month; black lines are means with \pm standard deviations shaded. Insets list the number of MDN sites. Model results are averaged over each of the $4^{\circ} \times 20^{\circ}$ regions shown.

model, but we focus this analysis on the shape of the vertical profile rather than the absolute values, since the model is unbiased relative to observations at surface sites (Sect. 3.1). CARIBIC and ARCTAS observations here exclude biomass burning plumes $\left(\mathrm{CO}>200 \mathrm{ppb}\right.$ or $\left.\mathrm{CH}_{3} \mathrm{CN}>0.25 \mathrm{ppt}\right)$ because the model uses monthly climatological fire emissions.

The observations show boundary layer enhancements over Mexico and the subtropical Pacific Ocean, indicative of surface emissions, and ubiquitous MDEs in the Arctic boundary layer in spring (H. Mao et al., 2010). The model is consistent with these features. Otherwise the concentrations are uniform with altitude in the troposphere, both in the model and the observations, reflecting the long atmospheric lifetime of 


\section{A. INTEX-B}

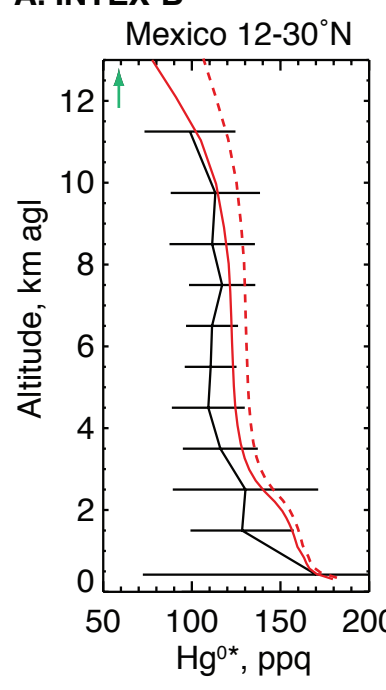

B. CARIBIC

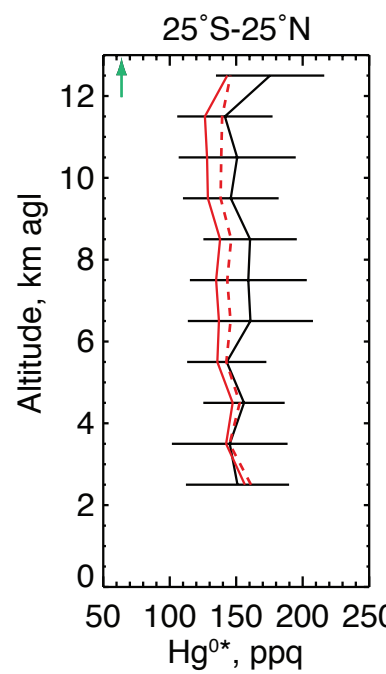

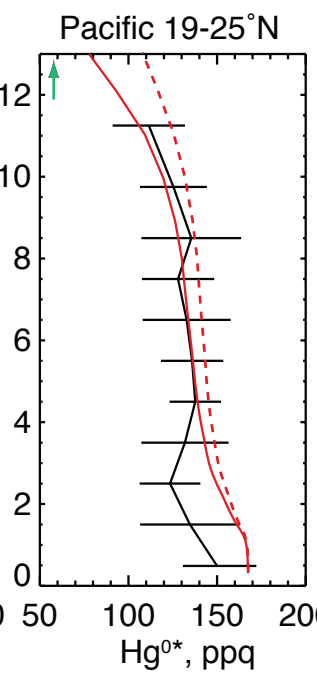

$30-65^{\circ} \mathrm{N}$

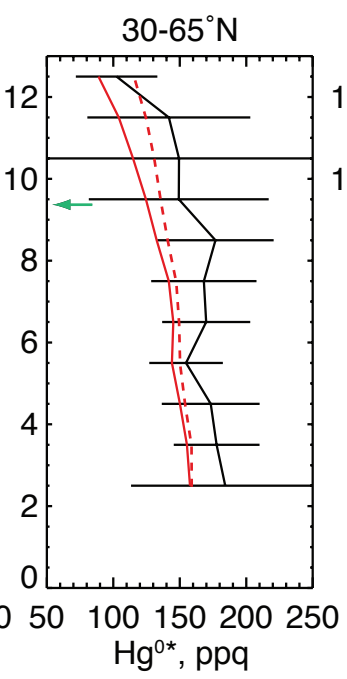

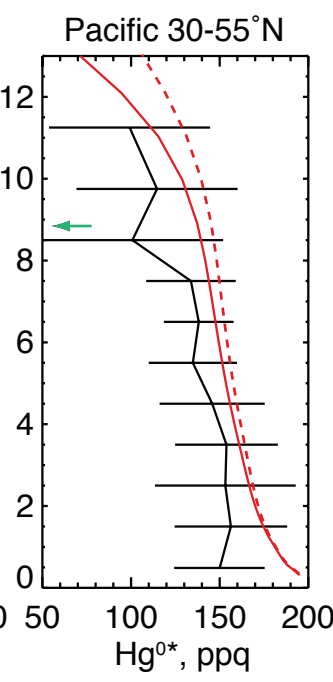

C. ARCTAS

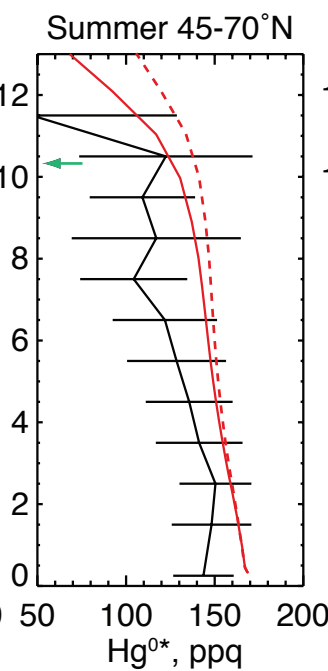

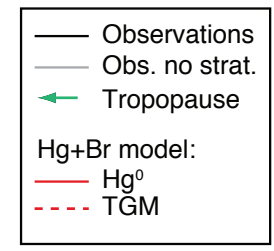

\section{(1)}
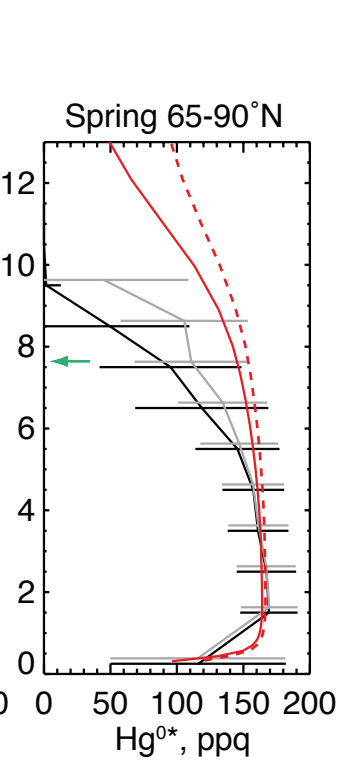

Fig. 11. Mean vertical profiles and standard deviations of mercury concentrations measured by aircraft and compared to the $\mathrm{Hg}+\mathrm{Br}$ model. (A) INTEX-B over Mexico during March 2006 and over the North Pacific Ocean during April-May 2006 (Talbot et al., 2008 ; Singh et al., 2009). We correct a low bias of $40 \%$ in the observations based on an in-flight intercomparison (Swartzendruber et al., 2008). (B) CARIBIC flights over Europe, Asia, Africa, and the Atlantic Ocean during 2005-2008 (Slemr et al., 2009). (C) ARCTAS flights over North America and the Arctic Ocean in summer $2008\left(45-70^{\circ} \mathrm{N}\right)$ and spring $2008\left(65-90^{\circ} \mathrm{N}\right)$ (H. Mao et al., 2010). Arrows show observed mean tropopause $\left(\mathrm{O}_{3}=100 \mathrm{ppb}\right)$. Gray lines in the lower right panel show data for troposphere only. Model results show $\mathrm{Hg}^{0}$ and TGM monthly mean mixing ratios over each flight region (INTEX-B and ARCTAS) or instantaneous values along the flight track (CARIBIC). Altitudes are above ground level. Note the different horizontal scales. See text for definition of $\mathrm{Hg}^{0 *}$.

$\mathrm{Hg}^{0}$. Of most interest here is the observed decline of concentrations above the tropopause. This decline is generally reproduced in the model if we assume that measurements quantify $\mathrm{Hg}^{0}$ only (or equivalently that $\mathrm{Hg}^{\mathrm{II}}$ is present mainly in the aerosol). Vertical gradients across and above the tropopause are similar in the $\mathrm{Hg}+\mathrm{Br}$ and $\mathrm{Hg}+\mathrm{OH} / \mathrm{O}_{3}$ simulations, and so do not provide an effective test of the chemical mechanism.
One prominent discrepancy is the inability of the model to simulate the steep decline above the tropopause in the Arctic springtime. Complete $\mathrm{Hg}^{0 *}$ depletions were common during ARCTAS in stratospheric air with $\mathrm{O}_{3}>100 \mathrm{ppb}$, and $\mathrm{Hg}^{0}$ * was rarely detectable when $\mathrm{O}_{3}$ exceeded $200 \mathrm{ppb}$, suggesting that oxidation increases abruptly above the tropopause (Talbot et al., 2007; Kim et al., 2009). We tested whether additional $\mathrm{Br}$ could be responsible by doubling it in the model throughout the stratosphere, corresponding to $4 \mathrm{ppt} \mathrm{BrO}$ in 
the lowermost stratosphere. Simulated $\mathrm{Hg}^{0}$ decreased by only $10 \mathrm{ppq}$ at $10 \mathrm{~km}$. Much higher bromine concentrations are unlikely based on satellite observations (Chance, 1998) and constraints on the stratospheric bromine budget (Liang et al., 2010; Salawitch et al., 2010). In another sensitivity test, we added $\mathrm{Hg}^{0}$ oxidation by $\mathrm{BrO}$ to the model (Raofie and Ariya, 2004), but this reaction enhanced $\mathrm{Hg}^{0}$ oxidation throughout the column rather than specifically in the stratosphere.

Additional oxidants in the springtime polar stratosphere might include $\mathrm{Cl}, \mathrm{Cl}_{2}$, and $\mathrm{BrCl}$ generated by heterogeneous chemistry. $\mathrm{Hg}^{0}$ oxidation reactions with these species are fast (Ariya et al., 2002; Donohoue et al., 2005) but limited by the low oxidant concentrations. The GMI Aura model predicts mean values of $\sim 1 \mathrm{ppt} \mathrm{ClO}$ in the lowermost stratosphere during spring ARCTAS, corresponding to $0.5 \mathrm{ppq} \mathrm{Cl}$ and up to 100 ppt $\mathrm{Cl}_{2}$ and $30 \mathrm{ppt} \mathrm{BrCl}$ (Strahan et al., 2007). Based on the available kinetic data (mainly $298 \mathrm{~K}$ ), the resulting lifetime of $\mathrm{Hg}^{0}$ exceeds 1 year, too long to account for $\mathrm{Hg}^{0}$ depletion. However, Thornton et al. (2003) observed much greater chlorine activation $(\sim 10 \mathrm{ppt} \mathrm{ClO})$ in the Arctic winter stratosphere than predicted by the GMI model. At these levels, $\mathrm{Cl}, \mathrm{Cl}_{2}$ and $\mathrm{BrCl}$ could become important $\mathrm{Hg}^{0}$ oxidants.

The ARCTAS flights over California and Nevada (Jacob et al., 2010) provided a first opportunity for detailed boundary layer mapping of a continental source region (Fig. 12). Polluted conditions during these flights caused intermittent low bias in one of the two instrument channels, which we correct by removing the lower value of each consecutive measurement pair. The highest concentrations were in biomass burning plumes sampled in both northern and southern California. The three most concentrated plumes had $\mathrm{Hg} / \mathrm{CO}$ enhancement ratios of $90-130 \mathrm{nmol} \mathrm{mol}^{-1}$ and the mean enhancement ratio for all fire plumes (identified by $\mathrm{CH}_{3} \mathrm{CN}>0.25 \mathrm{ppt}$ ) was $80 \mathrm{nmol} \mathrm{mol}^{-1}$. WeissPenzias et al. (2007) and Finley et al. (2009) found similar $\mathrm{Hg} / \mathrm{CO}$ enhancements $\left(136 \pm 60 \mathrm{nmol} \mathrm{mol}^{-1}\right)$ in the Pacific Northwest during summers 2004-2005, and Talbot and Mao (2009) found $60 \mathrm{nmol} \mathrm{mol}^{-1}$ during summer ARCTAS flights over Canada, which are similar to ratios of $70-240 \mathrm{nmol} \mathrm{mol}^{-1}$ observed worldwide (Ebinghaus et al., 2007; Friedli et al., 2009). Based on these measurements, we reduced the $\mathrm{Hg} / \mathrm{CO}$ emission ratio for biomass burning in GEOS-Chem to $100 \mathrm{nmol} \mathrm{mol}^{-1}$ in this work (previously $210 \mathrm{nmol} \mathrm{mol}^{-1}$ ), as discussed in Sect. 2.1.

Apart from the fire plumes, the California observations show highest $\mathrm{Hg}^{0 *}$ near industry and ports in Los Angeles and Long Beach. Typical concentrations exceeded 200 ppq throughout the Los Angeles basin, following a pattern that closely resembles the emission distribution in the EPA source inventory (EPA, 2008). A fresh anthropogenic plume with high $\mathrm{SO}_{2}$ encountered near the Mexican border does not correspond with any nearby sources in the inventory, suggesting that some industrial emissions in the border region

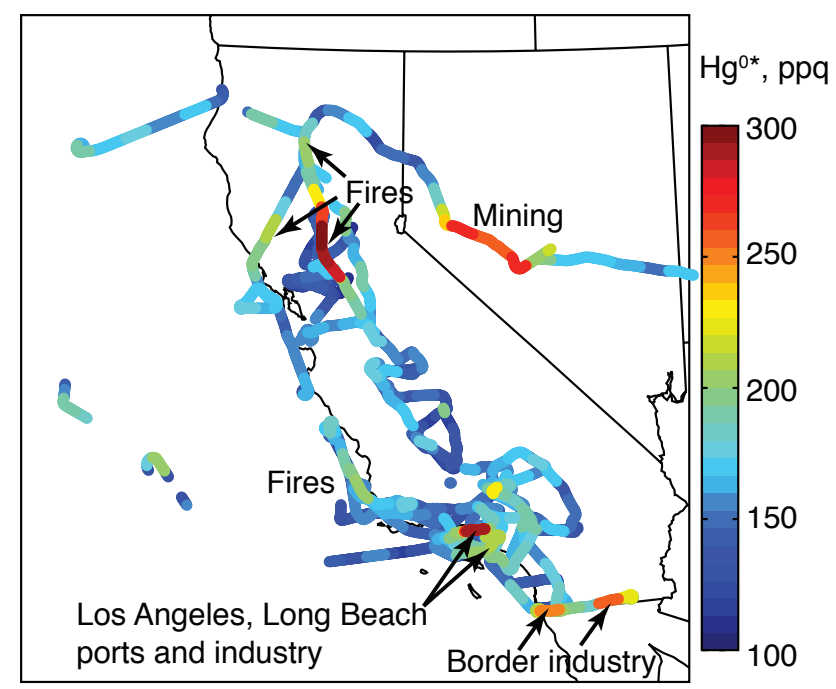

Fig. 12. Mercury distribution in the boundary layer ( $<2 \mathrm{~km}$ a.g.1.) during ARCTAS flights over California and Nevada (June 2008). Sources are identified through correlations with other species (CO, $\mathrm{O}_{3}, \mathrm{CH}_{3} \mathrm{CN}, \mathrm{HCN}$ ).

are underestimated. Offshore marine airmasses contained up to $200 \mathrm{ppq} \mathrm{Hg}^{0 *}$ as well as elevated dimethyl sulfide indicative of ocean emissions. Mercury levels also persisted above $220 \mathrm{ppq}$ for $150 \mathrm{~km}$ on a flight over active and inactive mines in western Nevada. These elevated concentrations are typical for summertime at surface sites in Nevada and may result from a mix of mining operations and naturally $\mathrm{Hg}$-enriched soils (Lyman and Gustin, 2008).

\subsection{Is atmospheric reduction necessary to explain observations?}

Global models of atmospheric mercury require atmospheric reduction of $4000-10000 \mathrm{Mg} \mathrm{a}^{-1} \mathrm{Hg}^{\mathrm{II}}$ to achieve an unbiased simulation of mean TGM observations with current emission inventories (Bergan and Rodhe, 2001; Lin et al., 2006; Seigneur et al., 2006; Selin et al., 2007, this work). While several reductants for $\mathrm{Hg}^{\mathrm{II}}$ have possible atmospheric relevance (see review by Ariya et al., 2008), atmospheric importance has not been established for any; so the role of $\mathrm{Hg}^{\mathrm{II}}$ reduction in the global atmosphere remains conjectural (Hynes et al., 2009). Fast reduction may occur in fresh power plant plumes (Edgerton et al., 2006; Landis et al., 2009), but the global effect would be small because the anthropogenic $\mathrm{Hg}^{\text {II }}$ source is only $700 \mathrm{Mg} \mathrm{a}^{-1}$. We find in our $\mathrm{Hg}+\mathrm{Br}$ model that all simulation results can be replicated without atmospheric reduction if we decrease the overall rate of $\mathrm{Hg}^{0}$ conversion to $\mathrm{Hg}^{\mathrm{II}}$ by $60 \%$. This could be accommodated within the range of theory-derived kinetic coefficients for the reaction $\mathrm{HgBr}+\mathrm{X} \rightarrow \mathrm{HgBrX}(\mathrm{X} \equiv \mathrm{Br}, \mathrm{OH})$ (Goodsite et al., 2004; Balabanov et al., 2005) or by smaller Br concentrations. Until better constraints on $\mathrm{Hg}^{0}$ oxidation rates 
are available, it appears that atmospheric reduction is not required to explain any of the major features of the global mercury cycle.

\section{Global mercury budget}

Figure 1 shows the global atmospheric mercury budget derived from our $\mathrm{Hg}+\mathrm{Br}$ simulation in GEOS-Chem. Emissions and deposition in our $\mathrm{Hg}+\mathrm{OH} / \mathrm{O}_{3}$ simulation differ from the figure by less than $10 \%$. The troposphere accounts for $99 \%$ of total atmospheric $\mathrm{Hg}^{0}$ but only $50 \%$ of $\mathrm{Hg}^{\mathrm{II}}$, reflecting the lack of $\mathrm{Hg}^{\mathrm{II}}$ chemical or depositional loss in the stratosphere. The $\mathrm{Hg}^{\mathrm{II}}$ burden in Fig. 1 includes inert particulate mercury $\mathrm{Hg}_{P}$ but it contributes only $2 \mathrm{Mg}$. Nearly all redox fluxes occur in the troposphere, as seen in Fig. 3.

Anthropogenic emissions here are $2050 \mathrm{Mg} \mathrm{a}^{-1}$ and total emissions are $8300 \mathrm{Mg} \mathrm{a}^{-1}$, both within the literature range as described in Sect. 2.1. Although the original GEOS-Chem model of Selin et al. (2007) used similar anthropogenic emissions $\left(2200 \mathrm{Mg} \mathrm{a}^{-1}\right)$, Selin et al. (2008) increased these to $3400 \mathrm{Mg} \mathrm{a}^{-1}$ to match observed TGM after adding $\mathrm{Hg}^{0}$ dry deposition to the model. Our $\mathrm{Hg}+\mathrm{Br}$ model matches observed TGM with smaller emissions because oxidation is slower, resulting in a longer atmospheric lifetime for mercury. Our $\mathrm{Hg}+\mathrm{OH} / \mathrm{O}_{3}$ model achieves the same result by assuming faster reduction. Atmospheric reduction can be eliminated entirely in the $\mathrm{Hg}+\mathrm{Br}$ model if the oxidation kinetic coefficients are reduced within their uncertainty, as described in Sect. 3.6.

Land in the model emits $1200 \mathrm{Mg} \mathrm{a}^{-1}$ from soils plus $260 \mathrm{Mga}^{-1}$ from rapid photoreduction of $\mathrm{Hg}^{\mathrm{II}}$ deposited to vegetation and $260 \mathrm{Mg} \mathrm{a}^{-1}$ from snow. Even though we eliminated mercury evapotranspiration, the total land emissions are unchanged from Selin et al. (2008) because of the constraint from preindustrial steady state. Mason (2009) extrapolated field flux measurements to estimate that terrestrial ecosystems emit $1650 \mathrm{Mga}^{-1}$ (range 860 $3800 \mathrm{Mg} \mathrm{a}^{-1}$ ) including primary geogenic sources but excluding biomass burning. In our model the corresponding emission is $2200 \mathrm{Mg} \mathrm{a}^{-1}$, well within that range.

Most atmospheric mercury is removed as $\mathrm{Hg}^{\mathrm{II}}$ $\left(5100 \mathrm{Mg} \mathrm{a}^{-1}\right)$ with the spatial pattern shown in Fig. 13. Wet deposition accounts for $3100 \mathrm{Mg} \mathrm{a}^{-1}$ and dry deposition for $800 \mathrm{Mg} \mathrm{a}^{-1}$. Sea-salt particles take up an additional $1200 \mathrm{Mg} \mathrm{a}^{-1}$ and this accounts for $35 \%$ of $\mathrm{Hg}^{\mathrm{II}}$ deposition to the ocean. Global $\mathrm{Hg}^{0}$ dry deposition is $3200 \mathrm{Mg} \mathrm{a}^{-1}$, but emissions offset this so that oceans and soils everywhere are net sources of atmospheric $\mathrm{Hg}^{0}$. After accounting for all mercury species, the deep ocean in the model sequesters $1600 \mathrm{Mg} \mathrm{a}^{-1}$ from the atmosphere, similar to the previous GEOS-Chem model version $\left(2100 \mathrm{Mg} \mathrm{a}^{-1}\right.$ ) (Selin et al., 2008).

The $\mathrm{Hg}+\mathrm{OH} / \mathrm{O}_{3}$ model generates a very different $\mathrm{Hg}^{\mathrm{II}}$ deposition pattern from the $\mathrm{Hg}+\mathrm{Br}$ model, except for close

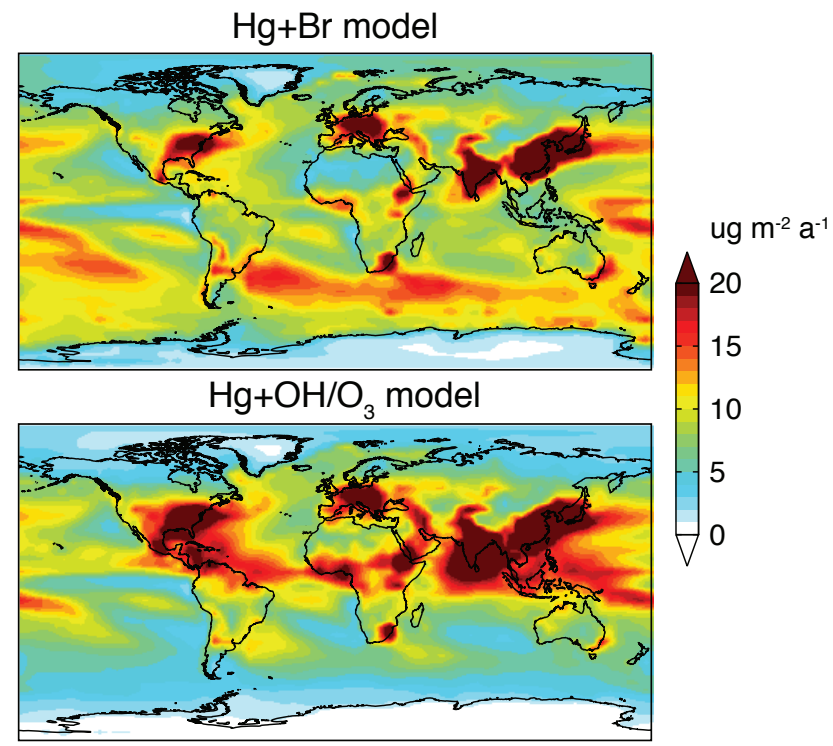

Fig. 13. Annual deposition fluxes of $\mathrm{Hg}^{\mathrm{II}}$ plus $\mathrm{Hg}_{\mathrm{P}}$ in the $\mathrm{Hg}+\mathrm{Br}$ and $\mathrm{Hg}+\mathrm{OH} / \mathrm{O}_{3}$ models. Both models have $5100 \mathrm{Mg} \mathrm{a}^{-1}$ total deposition.

to $\mathrm{Hg}^{\mathrm{II}}$ sources, as seen in Fig. 13. With the $\mathrm{Hg}+\mathrm{OH} / \mathrm{O}_{3}$ oxidation mechanism, deposition is largest in the tropics where $[\mathrm{OH}]$ is greatest and deep convective rain occurs frequently. The $\mathrm{Hg}+\mathrm{Br}$ model has greater $\mathrm{Hg}^{\mathrm{II}}$ deposition in the Southern Hemisphere due to the oxidation differences seen in Fig. 3. Despite these large-scale differences, both oxidation mechanisms predict similar wet deposition at monitoring sites in North America and Europe because of the anthropogenic influence (see Sect. 3.4). Figure 13 implies that wet deposition measurements in the tropics and Southern Hemisphere could distinguish between oxidation mechanisms. Furthermore, the $\mathrm{Hg}+\mathrm{Br}$ model suggests that mercury inputs to Southern Ocean ecosystems may be much greater than previously thought.

\section{Conclusions}

We have added $\mathrm{Hg}^{0}$ oxidation by gas-phase bromine atoms to a global 3-D atmospheric model (GEOS-Chem) to test whether this reaction is consistent with the observed patterns of atmospheric mercury concentration and deposition. We compare the model performance with $\mathrm{Br}$ as the sole oxidant (" $\mathrm{Hg}+\mathrm{Br}$ model") against a model in which $\mathrm{OH}$ and ozone are the only oxidants (" $\mathrm{Hg}+\mathrm{OH} / \mathrm{O}_{3}$ model"). While both oxidation mechanisms, and possibly others, may operate together in the real atmosphere, these idealized simulations enable us to explore the constraints that observations place on the atmospheric chemistry of mercury.

Total mercury emissions in the model are $8300 \mathrm{Mg} \mathrm{a}^{-1}$, including $2050 \mathrm{Mg} \mathrm{a}^{-1}$ from anthropogenic sources. A new 
snowpack reservoir stores deposited mercury and reemits it under sunlight at a temperature-dependent rate. The seasonal cycle of Arctic $\mathrm{Hg}^{0}$ implies that $60 \%$ of mercury deposited to snow is eventually reemitted while the remainder $\left(60 \mathrm{Mg} \mathrm{a}^{-1}\right)$ transfers to the ocean and soils.

$\mathrm{Hg}+\mathrm{Br}$ kinetics here follow Goodsite et al. (2004) and Donohoue et al. (2006), while $\mathrm{Hg}+\mathrm{OH} / \mathrm{O}_{3}$ kinetics are identical to Selin et al. (2008). Global bromine distributions derive from tropospheric and stratospheric chemistry models, which are constrained by precursor gas measurements. We also specify $\mathrm{BrO}$ concentrations in the marine and polar springtime boundary layer based on observations. $\mathrm{Hg}^{0}$ has a 6 month chemical lifetime in the $\mathrm{Hg}+\mathrm{Br}$ model and a 3.7 month lifetime in the $\mathrm{Hg}+\mathrm{OH} / \mathrm{O}_{3}$ model. Matching atmospheric observations with the imposed anthropogenic emission inventory requires an atmospheric lifetime of 7.3 months for TGM, which we achieve by invoking photochemical reduction of $\mathrm{Hg}^{\mathrm{II}}$ in clouds (at a faster rate in the $\mathrm{Hg}+\mathrm{OH} / \mathrm{O}_{3}$ model). This reduction would be unnecessary in the $\mathrm{Hg}+\mathrm{Br}$ model if we decreased the overall $\mathrm{Hg}^{0}$ oxidation rate by $60 \%$, which is within the uncertainty of the $\mathrm{HgBr}+\mathrm{X}+\mathrm{M}$ reaction step.

The $\mathrm{Hg}+\mathrm{Br}$ and $\mathrm{Hg}+\mathrm{OH} / \mathrm{O}_{3}$ models both provide unbiased simulations of TGM surface concentrations and their spatial variance. In particular, the $\mathrm{Hg}+\mathrm{Br}$ model reproduces the interhemispheric gradient of TGM, which contradicts an earlier study (Seigneur and Lohman, 2008). Observed seasonal cycles of TGM at mid-latitudes are also consistent with both models. However, only the $\mathrm{Hg}+\mathrm{Br}$ model reproduces the spring depletion and summer rebound observed at polar sites. The $\mathrm{Hg}+\mathrm{Br}$ model also provides a better simulation of $\mathrm{Hg}^{0}$ oxidation during subsidence events over Antarctica.

Wet deposition flux patterns of mercury observed over Europe and North America are generally reproduced in the model. Simulated deposition in the Northeast US in winter is too high regardless of oxidant, which could reflect excessive scavenging by snow, reduction of $\mathrm{Hg}^{\mathrm{II}}$ in power plant plumes, or speciation error in the emission inventory. The Southeast US summer maximum in mercury wet deposition is better simulated by the $\mathrm{Hg}+\mathrm{OH} / \mathrm{O}_{3}$ model, where it reflects scavenging of $\mathrm{Hg}^{\mathrm{II}}$ from the free troposphere by deep convection.

Vertical profiles from CARIBIC, INTEX-B, and ARCTAS aircraft show uniform concentrations in the troposphere and declines above the tropopause. We reproduce these features in the $\mathrm{Hg}+\mathrm{Br}$ model except in Arctic spring where the observed stratospheric depletion is strongest. Neither $\mathrm{Br}$ nor $\mathrm{BrO}$ can explain the extreme stratospheric $\mathrm{Hg}^{0}$ depletion in Arctic spring and the $\mathrm{Hg}+\mathrm{OH} / \mathrm{O}_{3}$ model does no better. We suggest that $\mathrm{Cl}, \mathrm{Cl}_{2}$, or $\mathrm{BrCl}$ might be important in the springtime stratosphere, and estimate that the required concentrations are within the range of $\mathrm{ClO}$ observations.

Two major effects of using $\mathrm{Br}$ as the $\mathrm{Hg}^{0}$ oxidant instead of $\mathrm{OH}$ and ozone are to lower $\mathrm{Hg}^{0}$ concentrations in the Southern Hemisphere and to increase mercury deposition to the Southern Ocean. The $\mathrm{Hg}+\mathrm{OH} / \mathrm{O}_{3}$ model, in contrast, has peak deposition in the tropics. Mercury concentration and deposition data in the tropics and southern mid-latitudes would be necessary to test these patterns.

Our results show that gas-phase bromine is viable as the main global oxidant for $\mathrm{Hg}^{0}$, producing a TGM lifetime and distribution consistent with nearly all available observations. Most of the oxidation occurs in the free troposphere where $\mathrm{Br}$ concentrations are constrained by bromocarbon measurements. We also find that atmospheric reduction of $\mathrm{Hg}^{\mathrm{II}}$ may not be necessary to match observed $\mathrm{Hg}^{0}$ concentrations if we decrease $\mathrm{Hg}^{0}$ oxidation kinetics within its uncertainties.

Acknowledgements. We thank Oleg Travnikov for providing quality-controled EMEP wet deposition measurements, Ralf Ebinghaus and Hans Kock for CARIBIC support, and Ernst-Günther Brunke for supporting Cape Point operations. $\mathrm{CDH}$ appreciates helpful comments from Elsie Sunderland. This work was supported by the Atmospheric Chemistry Program of the US National Science Foundation, by the Electric Power Research Institute (EPRI) and by a US Environmental Protection Agency (EPA) STAR Graduate Fellowship to CDH. Statements in this publication reflect the author's professional views and opinions and should not be construed to represent any determination or policy of the US EPA.

Edited by: J. W. Bottenheim

\section{References}

Ababneh, F. A., Scott, S. L., Al-Reasi, H. A., and Lean, D. R. S.: Photochemical reduction and reoxidation of aqueous mercuric chloride in the presence of ferrioxalate and air, Sci. Total Environ., 367, 831-839, doi:10.1016/j.scitotenv.2006.02.018, 2006.

Ariya, P. A., Khalizov, A., and Gidas, A.: Reactions of gaseous mercury with atomic and molecular halogens: Kinetics, product studies, and atmospheric implications, J. Phys. Chem. A, 106, 7310-7320, doi:10.1021/jp020719o, 2002.

Ariya, P., Dastoor, A., Amyot, M., Schroeder, W., Barrie, L., Anlauf, K., Raofie, F., Ryzhkov, A., Davignon, D., Lalonde, J., and Steffen, A.: The Arctic: a sink for mercury, Tellus B, 56, $397-$ 403, 2004.

Ariya, P. A., Skov, H., Grage, M. M. L., and Goodsite, M. E.: Gaseous elemental mercury in the ambient atmosphere: Review of the application of theoretical calculations and experimental studies for determination of reaction coefficients and mechanisms with halogens and other reactants, Adv. Quantum. Chem., 55, 43-55, doi:10.1016/S0065-3276(07)00204-3, 2008.

Ariya, P., Peterson, K., Snider, G., and Amyot, M.: Mercury chemical transformation in the gas, aqueous and heterogeneous phases: state-of-the-art science and uncertainties, in: Mercury Fate and Transport in the Global Atmosphere, edited by: Pirrone, N. and Mason, R. P., Springer, 2009.

Aspmo, K. and Berg, T.: "Long-term" Antarctic measurements of atmospheric mercury, in: 9th International Conference on Mercury as a Global Pollutant, Guiyang, China, 2009.

Balabanov, N., Shepler, B., and Peterson, K.: Accurate global potential energy surface and reaction dynamics for the 
ground state of $\mathrm{HgBr}_{2}$, J. Phys. Chem. A, 109, 8765-8773, doi:10.1021/jp0534151, 2005.

Bergan, T. and Rodhe, H.: Oxidation of elemental mercury in the atmosphere; Constraints imposed by global scale modelling, J. Atmos. Chem., 40, 191-212, 2001.

Brooks, S., Saiz-Lopez, A., Skov, H., Lindberg, S., Plane, J., and Goodsite, M.: The mass balance of mercury in the springtime Arctic environment, Geophys. Res. Lett., 33, L13812, doi:10.1029/2005GL025525, 2006.

Brooks, S., Arimoto, R., Lindberg, S., and Southworth, G.: Antarctic polar plateau snow surface conversion of deposited oxidized mercury to gaseous elemental mercury with fractional long-term burial, Atmos. Environ., 42, 2877-2884, doi:10.1016/j.atmosenv.2007.05.029, 2008.

Bullock, O. R., Atkinson, D., Braverman, T., Civerolo, K., Dastoor, A., Davignon, D., Ku, J.-Y., Lohman, K., Myers, T. C., Park, R. J., Seigneur, C., Selin, N. E., Sistla, G., and Vijayaraghavan, K.: An analysis of simulated wet deposition of mercury from the North American Mercury Model Intercomparison Study, J. Geophys. Res., 114, D08301, doi:10.1029/2008JD011224, 2009.

Burrows, J., Weber, M., Buchwitz, M., Rozanov, V., LadstatterWeissenmayer, A., Richter, A., DeBeek, R., Hoogen, R., Bramstedt, K., Eichmann, K., and Eisinger, M.: The global ozone monitoring experiment (GOME): Mission concept and first scientific results, J. Atmos. Sci., 56, 151-175, 1999.

Butler, T. J., Cohen, M. D., Vermeylen, F. M., Likens, G. E., Schmeltz, D., and Artz, R. S.: Regional precipitation mercury trends in the eastern USA, 1998-2005: Declines in the Northeast and Midwest, no trend in the Southeast, Atmos. Environ., 42, 1582-1592, doi:10.1016/j.atmosenv.2007.10.084, 2008.

Caldwell, C., Swartzendruber, P., and Prestbo, E.: Concentration and dry deposition of mercury species in arid south central New Mexico (2001-2002), Environ. Sci. Technol., 40, 7535-7540, 2006.

Calvert, J. and Lindberg, S.: Mechanisms of mercury removal by $\mathrm{O}_{3}$ and $\mathrm{OH}$ in the atmosphere, Atmos. Environ., 39, 3355-3367, doi:10.1016/j.atmosenv.2005.01.055, 2005.

Chance, K.: Analysis of BrO measurements from the Global Ozone Monitoring Experiment, Geophys. Res. Lett., 25, 3335-3338, 1998.

Choi, H.-D., Holsen, T. M., and Hopke, P. K.: Atmospheric mercury $(\mathrm{Hg})$ in the Adirondacks: Concentrations and sources, Environ. Sci. Technol., 42, 5644-5653, doi:10.1021/es7028137, 2008.

Cobbett, F. D., Steffen, A., Lawson, G., and Heyst, B. J. V.: GEM fluxes and atmospheric mercury concentrations (GEM, RGM and Hg-P) in the Canadian Arctic at Alert, Nunavut, Canada (February-June 2005), Atmos. Environ., 41, 6527-6543, doi:10.1016/j.atmosenv.2007.04.033, 2007.

Cohen, M., Artz, R., Draxler, R., Miller, P., Poissant, L., Niemi, D., Ratte, D., Deslauriers, M., Duval, R., Laurin, R., Slotnick, J., Nettesheim, T., and McDonald, J.: Modeling the atmospheric transport and deposition of mercury to the Great Lakes, Environ. Res., 95, 247-265, doi:10.1016/j.envres.2003.11.007, 2004.

Dastoor, A. P., Davignon, D., Theys, N., Roozendael, M. V., Steffen, A., and Ariya, P. A.: Modeling dynamic exchange of gaseous elemental mercury at polar sunrise, Environ. Sci. Technol., 42, 5183-5188, doi:10.1021/es800291w, 2008.

Dommergue, A., Ferrari, C., Gauchard, P., Boutron, C., Poissant, L., Pilote, M., Jitaru, P., and Adams, F.: The fate of mercury species in a sub-Arctic snowpack during snowmelt, Geophys. Res. Lett., 30, 1621, doi:10.1029/2003GL017308, 2003.

Donohoue, D., Bauer, D., and Hynes, A.: Temperature and pressure dependent rate coefficients for the reaction of $\mathrm{Hg}$ with $\mathrm{Cl}$ and the reaction of $\mathrm{Cl}$ with $\mathrm{Cl}$ : A pulsed laser photolysis-pulsed laser induced fluorescence study, J. Phys. Chem. A, 109, 7732-7741, doi:10.1021/jp0513541, 2005.

Donohoue, D., Bauer, D., Cossairt, B., and Hynes, A.: Temperature and pressure dependent rate coefficients for the reaction of $\mathrm{Hg}$ with $\mathrm{Br}$ and the reaction of $\mathrm{Br}$ with $\mathrm{Br}$ : A pulsed laser photolysispulsed laser induced fluorescence study, J. Phys. Chem. A, 110, 6623-6632, doi:10.1021/jp054688j, 2006.

Douglass, A., Stolarski, R., Strahan, S., and Connell, P.: Radicals and reservoirs in the GMI chemistry and transport model: Comparison to measurements, J. Geophys. Res., 109, D16302, doi:10.1029/2004JD004632, 2004.

Douglas, T. A., Sturm, M., Simpson, W. R., Blum, J. D., AlvarezAviles, L., Keeler, G. J., Perovich, D. K., Biswas, A., and Johnson, K.: Influence of snow and ice crystal formation and accumulation on mercury deposition to the Arctic, Environ. Sci. Technol., 42, 1542-1551, doi:10.1021/es070502d, 2008.

Ebinghaus, R., Slemr, F., Brenninkmeijer, C. A. M., van Velthoven, P., Zahn, A., Hermann, M., O'Sullivan, D. A., and Oram, D. E.: Emissions of gaseous mercury from biomass burning in South America in 2005 observed during CARIBIC flights, Geophys. Res. Lett., 34, L08813, doi:10.1029/2006GL028866, 2007.

Edgerton, E. S., Hartsell, B. E., and Jansen, J. J.: Mercury speciation in coal-fired power plant plumes observed at three surface sites in the southeastern US, Environ. Sci. Technol., 40, 45634570, doi:10.1021/es0515607, 2006.

EMEP: European Monitoring and Evaluation Programme: Cooperative programme for monitoring and evaluation of the longrange transmissions of air pollutants in Europe, available at: http://tarantula.nilu.no/projects/ccc/emepdata.html, 2009.

EPA: US Environmental Protection Agency, Office of Wetlands, Oceans and Watersheds, Watershed Branch: Model-Based Analysis and Tracking of Airborne Mercury Emissions to Assist in Watershed Planning, available at: http://www.epa.gov/owow/ tmdl/pdf/final300report_10072008.pdf, 2008.

Fain, X., Grangeon, S., Bahlmann, E., Fritsche, J., Obrist, D., Dommergue, A., Ferrari, C. P., Cairns, W., Ebinghaus, R., Barbante, C., Cescon, P., and Boutron, C.: Diurnal production of gaseous mercury in the alpine snowpack before snowmelt, J. Geophys. Res., 112, D21311, doi:10.1029/2007JD008520, 2007.

Faïn, X., Ferrari, C. P., Dommergue, A., Albert, M., Battle, M., Arnaud, L., Barnola, J.-M., Cairns, W., Barbante, C., and Boutron, C.: Mercury in the snow and firn at Summit Station, Central Greenland, and implications for the study of past atmospheric mercury levels, Atmos. Chem. Phys., 8, 3441-3457, doi:10.5194/acp-8-3441-2008, 2008.

Feng, J.: A size-resolved model for below-cloud scavenging of aerosols by snowfall, J. Geophys. Res., 114, D08203, doi:10.1029/2008JD011012, 2009.

Feng, X., Wang, S., Qiu, G., He, T., Li, G., Li, Z., and Shang, L.: Total gaseous mercury exchange between water and air during cloudy weather conditions over Hongfeng Reservoir, Guizhou, China, J. Geophys. Res.-Atmos., 113, D15309, doi:10.1029/2007JD009600, 2008.

Finley, B. D., Swartzendruber, P. C., and Jaffe, D. A.: Particulate 
mercury emissions in regional wildfire plumes observed at the Mount Bachelor Observatory, Atmos. Environ., 43, 6074-6083, doi:10.1016/j.atmosenv.2009.08.046, 2009.

Friedli, H. R., Arellano, A. F., Cinnirella, S., and Pirrone, N.: Initial estimates of mercury emissions to the atmosphere from global biomass burning, Environ. Sci. Technol., 43, 3507-3513, 2009.

Gårdfeldt, K. and Jonsson, M.: Is bimolecular reduction of $\mathrm{Hg}$ (II) complexes possible in aqueous systems of environmental importance, J. Phys. Chem. A, 107, 4478-4482, doi:10.1021/jp0275342, 2003.

Goodsite, M., Plane, J., and Skov, H.: A theoretical study of the oxidation of $\mathrm{Hg}^{0}$ to $\mathrm{HgBr}_{2}$ in the troposphere, Environ. Sci. Technol., 38, 1772-1776, doi:10.1021/es034680s, 2004.

Guentzel, J., Landing, W., Gill, G., and Pollman, C.: Processes influencing rainfall deposition of mercury in Florida, Environ. Sci. Technol., 35, 863-873, doi:10.1021/es001523+, 2001.

Gusev, A., Illiyn, I., Rozovskaya, O., Shatalov, V., Sokovych, V., and Travnikov, O.: Modelling of heavy metals and persistent organic pollutants: New developments, Tech. rep., EMEP/MSC-E, 2009.

Gustin, M., Ericksen, J., Schorran, D., Johnson, D., Lindberg, S., and Coleman, J.: Application of controlled mesocosms for understanding mercury air-soil-plant exchange, Environ. Sci. Technol., 38, 6044-6050, doi:10.1021/es0487933, 2004.

Hall, B.: The gas phase oxidation of elemental mercury by ozone, Water Air Soil Poll., 80, 301-315, 1995.

Hedgecock, I. and Pirrone, N.: Mercury and photochemistry in the marine boundary layer-modelling studies suggest the in situ production of reactive gas phase mercury, Atmos. Environ., 35, 3055-3062, 2001.

Hedgecock, I., Trunfio, G., Pirrone, N., and Sprovieri, F.: Mercury chemistry in the MBL: Mediterranean case and sensitivity studies using the AMCOTS (Atmospheric Mercury Chemistry over the Sea) model, Atmos. Environ., 39, 7217-7230, 2005.

Holmes, C., Jacob, D., and Yang, X.: Global lifetime of elemental mercury against oxidation by atomic bromine in the free troposphere, Geophys. Res. Lett., 33, L20808, doi:10.1029/2006GL027176, 2006.

Holmes, C. D., Jacob, D. J., Mason, R. P., and Jaffe, D. A.: Sources and deposition of reactive gaseous mercury in the marine atmosphere, Atmos. Environ., 43, 2278-2285, doi:10.1016/j.atmosenv.2009.01.051, 2009.

Hylander, L. D. and Meili, M.: The rise and fall of mercury: converting a resource to refuse after 500 years of mining and pollution, Crit. Rev. Environ. Sci. Technol., 34, 1-36, 2005.

Hynes, A., Donohoue, D., Goodsite, M., Hedgecock, I., Pirrone, N., and Mason, R.: Our current understanding of major chemical and physical processes affecting mercury dynamics in the atmosphere and at air-water/terrestrial interfaces, in: Mercury Fate and Transport in the Global Atmosphere, edited by: Pirrone, N. and Mason, R. P., chap. 14, Springer, 2009.

Jacob, D. J., Crawford, J. H., Maring, H., Clarke, A. D., Dibb, J. E., Emmons, L. K., Ferrare, R. A., Hostetler, C. A., Russell, P. B., Singh, H. B., Thompson, A. M., Shaw, G. E., McCauley, E., Pederson, J. R., and Fisher, J. A.: The Arctic Research of the Composition of the Troposphere from Aircraft and Satellites (ARCTAS) mission: design, execution, and first results, Atmos. Chem. Phys., 10, 5191-5212, doi:10.5194/acp-10-5191-2010, 2010.

Jaffe, D., Prestbo, E., Swartzendruber, P., Weiss-Penzias, P., Kato,
S., Takami, A., Hatakeyama, S., and Kajii, Y.: Export of atmospheric mercury from Asia, Atmos. Environ., 39, 3029-3038, doi:10.1016/j.atmosenv.2005.01.030, 2005.

Johnson, K. P., Blum, J. D., Keeler, G. J., and Douglas, T. A.: Investigation of the deposition and emission of mercury in arctic snow during an atmospheric mercury depletion event, J. Geophys. Res., 113, D17304, doi:10.1029/2008JD009893, 2008.

Kim, S., Talbot, R. W., and Mao, H.: 2009, Eos Transactions, Fall Meeting Suppl, 90, A43A-0190, 2009.

Kirk, J. L., Louis, V. L. S., and Sharp, M. J.: Rapid reduction and reemission of mercury deposited into snowpacks during atmospheric mercury depletion events at Churchill, Manitoba, Canada, Environ. Sci. Technol., 40, 7590-7596, doi:10.1021/es061299, 2006.

Lamborg, C., Rolfhus, K., Fitzgerald, W., and Kim, G.: The atmospheric cycling and air-sea exchange of mercury species in the South and equatorial Atlantic Ocean, Deep-sea Research II, 46, 957-977, 1999.

Lamborg, C., Fitzgerald, W., O'Donnell, J., and Torgersen, T.: A non-steady-state compartmental model of global-scale mercury biogeochemistry with interhemispheric atmospheric gradients, Geochim. Cosmochim. Ac., 66, 1105-1118, 2002.

Landis, M., Ryan, J., Oswald, E., Jansen, J., Monroe, L., Walters, J., Levin, L., ter Schure, A., Laudal, D., and Edgerton, E.: Plant Crist mercury plume study, in: Air Quality VII, Arlington, VA, October 27, 2009.

Laurier, F. and Mason, R.: Mercury concentration and speciation in the coastal and open ocean boundary layer, J. Geophys. Res., 112, D06302, doi:10.1029/2006JD007320, 2007.

Laurier, F., Mason, R., Whalin, L., and Kato, S.: Reactive gaseous mercury formation in the North Pacific Ocean's marine boundary layer: A potential role of halogen chemistry, J. Geophys. Res., 108, 4529, doi:10.1029/2003JD003625, 2003.

Leser, H., Honninger, G., and Platt, U.: MAX-DOAS measurements of $\mathrm{BrO}$ and $\mathrm{NO}_{2}$ in the marine boundary layer, Geophys. Res. Lett., 30, 1537, doi:10.1029/2002GL015811, 2003.

Liang, Q., Stolarski, R. S., Kawa, S. R., Nielsen, J. E., Douglass, A. R., Rodriguez, J. M., Blake, D. R., Atlas, E. L., and Ott, L. E.: Finding the missing stratospheric Bry: a global modeling study of $\mathrm{CHBr}_{3}$ and $\mathrm{CH}_{2} \mathrm{Br}_{2}$, Atmos. Chem. Phys., 10, 2269-2286, doi:10.5194/acp-10-2269-2010, 2010.

Lin, J.-T. and McElroy, M.: Impacts of boundary layer mixing on pollutant vertical profiles in the lower troposphere: Implications to satellite remote sensing, Atmos. Environ., 44, 1726-1739, doi:10.1016/j.atmosenv.2010.02.009, 2010.

Lin, C., Pongprueksa, P., Lindberg, S., Pehkonen, S., Byun, D., and Jang, C.: Scientific uncertainties in atmospheric mercury models I: Model science evaluation, Atmos. Environ., 40, 2911-2928, 2006.

Lindberg, S., Bullock, R., Ebinghaus, R., Engstrom, D., Feng, X., Fitzgerald, W., Pirrone, N., Prestbo, E., and Seigneur, C.: A synthesis of progress and uncertainties in attributing the sources of mercury in deposition, Ambio, 36, 19-32, 2007.

Lindqvist, O. and Rodhe, H.: Atmospheric mercury - a review, Tellus B, 37, 136-159, 1985.

Liu, H., Jacob, D., Bey, I., and Yantosca, R.: Constraints from Pb210 and Be-7 on wet deposition and transport in a global threedimensional chemical tracer model driven by assimilated meteorological fields, J. Geophys. Res., 106, 12109-12128, 2001. 
Liu, B., Keeler, G. J., Dvonch, J. T., Barres, J. A., Lynam, M. M., Marsik, F. J., and Morgan, J. T.: Temporal variability of mercury speciation in urban air, Atmos. Environ., 41, 1911-1923, doi:10.1016/j.atmosenv.2006.10.063, 2007.

Lohman, K., Seigneur, C., Edgerton, E., and Jansen, J.: Modeling mercury in power plant plumes, Environ. Sci. Technol., 40, 3848-3854, doi:10.1021/es051556v, 2006.

Lyman, S. N. and Gustin, M. S.: Speciation of atmospheric mercury at two sites in northern Nevada, USA, Atmos. Environ., 42, 927939, doi:10.1016/j.atmosenv.2007.10.012, 2008.

MacKenzie, D.: Seasonal variations in the mixing layer in the UTLS, in: GEOS-Chem User's Meeting, Cambridge, MA USA, 2009.

Mao, H., Talbot, R. W., Sive, B. C., Kim, S.-Y., Blake, D. R., and Weinheimer, A. J.: Arctic mercury depletion and its quantitative link with halogens, J. Atmos. Chem., in review, 2010.

Mao, J., Jacob, D. J., Evans, M. J., Olson, J. R., Ren, X., Brune, W. H., Clair, J. M. St., Crounse, J. D., Spencer, K. M., Beaver, M. R., Wennberg, P. O., Cubison, M. J., Jimenez, J. L., Fried, A., Weibring, P., Walega, J. G., Hall, S. R., Weinheimer, A. J., Cohen, R. C., Chen, G., Crawford, J. H., McNaughton, C., Clarke, A. D., Jaeglé, L., Fisher, J. A., Yantosca, R. M., Le Sager, P., and Carouge, C.: Chemistry of hydrogen oxide radicals $\left(\mathrm{HO}_{\mathrm{x}}\right)$ in the Arctic troposphere in spring, Atmos. Chem. Phys., 10, 58235838, doi:10.5194/acp-10-5823-2010, 2010.

Martin, M., Pöhler, D., Seitz, K., Sinreich, R., and Platt, U.: BrO measurements over the Eastern North-Atlantic, Atmos. Chem. Phys., 9, 9545-9554, doi:10.5194/acp-9-9545-2009, 2009.

Mason, R. P.: Mercury emissions from natural processes and their importance in the global mercury cycle, in: Mercury Fate and Transport in the Global Atmosphere, edited by: Pirrone, N. and Mason, R. P., chap. 7, Springer, 2009.

Mason, R. and Sheu, G.: Role of the ocean in the global mercury cycle, Global Biogeochem. Cy., 16, 1093, doi:10.1029/2001GB001440, 2002.

Murakami, M., Kimura, T., Magono, C., and Kikuchi, K.: Observations of precipitation scavenging for water-soluble particles, J. Meteorol. Soc. Jpn., 61, 346-358, 1983.

National Atmospheric Deposition Program: Mercury Deposition Network (MDN): A NADP Network, available at: http://nadp. sws.uiuc.edu/MDN/, 2009.

Nguyen, H. T., Kim, K.-H., Kim, M.-Y., Hong, S., Youn, Y.-H., Shon, Z.-H., and Lee, J. S.: Monitoring of atmospheric mercury at a global atmospheric watch (GAW) site on An-Myun Island, Korea, Water Air Soil Poll., 185, 149-164, doi:10.1007/s11270007-9438-5, 2007.

O'Brien, L. M., Harris, N. R. P., Robinson, A. D., Gostlow, B., Warwick, N., Yang, X., and Pyle, J. A.: Bromocarbons in the tropical marine boundary layer at the Cape Verde Observatory - measurements and modelling, Atmos. Chem. Phys., 9, 90839099, doi:10.5194/acp-9-9083-2009, 2009.

Pacyna, E. G., Pacyna, J. M., Steenhuisen, F., and Wilson, S.: Global anthropogenic mercury emission inventory for 2000, Atmos. Environ., 40, 4048-4063, doi:10.1016/j.atmosenv.2006.03.041, 2006.

Pacyna, J. M., Pacyna, E. G., and Aas, W.: Changes of emissions and atmospheric deposition of mercury, lead, and cadmium, Atmos. Environ., 43, 117-127, doi:10.1016/j.atmosenv.2008.09.066, 2009.
Pacyna, E. G., Pacyna, J. M., Sundseth, K., Munthe, J., Kindbom, K., Wilson, S., Steenhuisen, F., and Maxson, P.: Global emission of mercury to the atmosphere from anthropogenic sources in 2005 and projections to 2020, Atmos. Environ., 44, 2487-2499, doi:10.1016/j.atmosenv.2009.06.009, 2010.

Park, R., Jacob, D., Field, B., Yantosca, R., and Chin, M.: Natural and transboundary pollution influences on sulfate-nitrateammonium aerosols in the United States: implications for policy, J. Geophys. Res., 109, D15204, doi:10.1029/2003JD004473, 2004.

Parrella, J. P., Evans, M. J., Jacob, D. J., Liang, Q., Mickley, L. J., Miller, B., Pyle, J. A., and Yang, X.: Effect of bromine chemistry on natural tropospheric ozone: improved simulation of concentrations from the turn of the 20th century, Nature, in preparation, 2010.

Pehkonen, S. and Lin, C.: Aqueous photochemistry of mercury with organic acids, J. Air Waste Manage., 48, 144-150, 1998.

Petersen, G., Bloxam, R., Wong, S., Munthe, J., Kruger, O., Schmolke, S., and Kumar, A.: A comprehensive Eulerian modelling framework for airborne mercury species: model development and applications in Europe, Atmos. Environ., 35, 30633074, 2001.

Pirrone, N., Cinnirella, S., Feng, X., Finkelman, R. B., Friedli, H. R., Leaner, J., Mason, R., Mukherjee, A. B., Stracher, G. B., Streets, D. G., and Telmer, K.: Global mercury emissions to the atmosphere from anthropogenic and natural sources, Atmos. Chem. Phys., 10, 5951-5964, doi:10.5194/acp-10-59512010, 2010.

Platt, U. and Janssen, C.: Observation and role of the free radicals $\mathrm{NO}_{3}, \mathrm{ClO}, \mathrm{BrO}$ and $\mathrm{IO}$ in the troposphere, Faraday Discuss., 100, 175-198, 1995.

Pongprueksa, P., Lin, C.-J., Lindberg, S. E., Jang, C., Braverman, T., Bullock, O. R., Ho, T. C., and Wei Chu, H.: Scientific uncertainties in atmospheric mercury models III: Boundary and initial conditions, model grid resolution, and $\mathrm{Hg}$ (II) reduction mechanism, Atmos. Environ., 42, 1828-1845, doi:10.1016/j.atmosenv.2007.11.020, 2008.

Prestbo, E. M. and Gay, D. A.: Wet deposition of mercury in the US and Canada, 1996-2005: Results and analysis of the NADP mercury deposition network (MDN), Atmos. Environ., 43, 42234233, doi:10.1016/j.atmosenv.2009.05.028, 2009.

Pruppacher, H. R. and Jaenicke, R.: The processing of water-vapor and aerosols by atmospheric clouds, a global estimate, Atmos. Res., 38, 283-295, 1995.

Pszenny, A. A. P., Moldanová, J., Keene, W. C., Sander, R., Maben, J. R., Martinez, M., Crutzen, P. J., Perner, D., and Prinn, R. G.: Halogen cycling and aerosol $\mathrm{pH}$ in the Hawaiian marine boundary layer, Atmos. Chem. Phys., 4, 147-168, doi:10.5194/acp-4147-2004, 2004.

Pundt, I., Pommereau, J., Chipperfield, M., Roozendael, M. V., and Goutail, F.: Climatology of the stratospheric BrO vertical distribution by balloon-borne UV-visible spectrometry, J. Geophys. Res., 107, 4806, doi:10.1029/2002JD002230, 2002.

Raofie, F. and Ariya, P.: Product study of the gas-phase BrOinitiated oxidation of $\mathrm{Hg}^{0}$ : evidence for stable $\mathrm{Hg} 1+$ compounds, Environ. Sci. Technol., 38, 4319-4326, doi:10.1021/es035339a, 2004.

Richter, A., Wittrock, F., Ladstatter-Weissenmayer, A., and Burrows, J.: GOME measurements of stratospheric and tropospheric 
BrO, Adv. Space Res., 29, 1667-1672, 2002.

Rutter, A. P. and Schauer, J. J.: The impact of aerosol composition on the particle to gas partitioning of reactive mercury, Environ. Sci. Technol., 41, 3934-3939, doi:10.1021/es062439i, 2007a.

Rutter, A. P. and Schauer, J. J.: The effect of temperature on the gas-particle partitioning of reactive mercury in atmospheric aerosols, Atmos. Environ., 41, 8647-8657, doi:10.1016/j.atmosenv.2007.07.024, 2007b.

Saiz-Lopez, A., Plane, J., and Shillito, J.: Bromine oxide in the midlatitude marine boundary layer, Geophys. Res. Lett., 31, L03111, doi:10.1029/2003GL018956, 2004.

Sakata, M. and Asakura, K.: Estimating contribution of precipitation scavenging of atmospheric particulate mercury to mercury wet deposition in Japan, Atmos. Environ., 41, 1669-1680, doi:10.1016/j.atmosenv.2006.10.031, 2007.

Salawitch, R., Weisenstein, D., Kovalenko, L., Sioris, C., Wennberg, P., Chance, K., Ko, M., and McLinden, C.: Sensitivity of ozone to bromine in the lower stratosphere, Geophys. Res. Lett., 32, L05811, doi:10.1029/2004GL021504, 2005.

Salawitch, R. J., Canty, T. P., Kurosu, T. P., Chance, K., Liang, Q., da Silva, A., Pawson, S., Nielsen, J. E., Rodriguez, J. M., Bhartia, P. K., Liu, X., Huey, L. G., Liao, J., Stickel, R. E., Tanner, D., Dibb, J. E., Simpson, W. R., Donohoue, D., Weinheimer, A. J., Flock, F. M., Knapp, D. J., Dmontzka, D. D., Neuman, J., Nowak, J. B., Ryerson, T. B., Oltmans, S., Blake, D. R., Atlas, E. L., Kinnison, D. E., Tilmes, S., Pan, L., Hendrick, F., Van Roozendael, M., Kreher, K., Johnston, P. V., Gao, R. S., Bui, T. P., Chen, G., Pierce, R., Crawford, J. H., and Jacob, D. J.: A new interpretation of total column $\mathrm{BrO}$ during Arctic spring, Geophys. Res. Lett., 37, L21805, doi:10.1029/2010GL043798, 2010.

Sander, S. P., Ravishankara, A. R., Golden, D. M., Kolb, C. E., Kurylo, M. J., Molina, M. J., Moortgat, G. K., Finlayson-Pitts, B. J., Wine, P. H., and Huie, R. E.: Chemical Kinetics and Photochemical Data for Use in Atmospheric Studies: Evaluation Number 15, Tech. rep., NASA Panel for Data Evaluation, available at: http://jpldataeval.jpl.nasa.gov/, 2006.

Seigneur, C. and Lohman, K.: Effect of bromine chemistry on the atmospheric mercury cycle, J. Geophys. Res., 113, D23309, doi:10.1029/2008JD010262, 2008.

Seigneur, C., Vijayaraghavan, K., and Lohman, K.: Atmospheric mercury chemistry: Sensitivity of global model simulations to chemical reactions, J. Geophys. Res., 111, D22306, doi:10.1029/2005JD006780, 2006.

Selin, N. E. and Jacob, D. J.: Seasonal and spatial patterns of mercury wet deposition in the United States: Constraints on the contribution from North American anthropogenic sources, Atmos. Environ., 42, 5193-5204, doi:10.1016/j.atmosenv.2008.02.069, 2008.

Selin, N. E., Jacob, D. J., Park, R. J., Yantosca, R. M., Strode, S., Jaeglé, L., and Jaffe, D.: Chemical cycling and deposition of atmospheric mercury: Global constraints from observations, J. Geophys. Res., 112, 1-14, doi:10.1029/2006JD007450, 2007.

Selin, N. E., Jacob, D. J., Yantosca, R. M., Strode, S., Jaeglé, L., and Sunderland, E. M.: Global 3-D land-ocean-atmosphere model for mercury: Present-day versus preindustrial cycles and anthropogenic enrichment factors for deposition, Global Biogeochem. Cyc., 22, 1-13, doi:10.1029/2007GB003040, 2008.

Shia, R., Seigneur, C., Pai, P., Ko, M., and Sze, N.: Global sim- ulation of atmospheric mercury concentrations and deposition fluxes, J. Geophys. Res., 104, 23747-23760, 1999.

$\mathrm{Si}$, L. and Ariya, P. A.: Reduction of oxidized mercury species by dicarboxylic acids (C-2-C-4): Kinetic and product studies, Environ. Sci. Technol., 42, 5150-5155, doi:10.1021/es800552z, 2008.

Sigler, J. M., Mao, H., and Talbot, R.: Gaseous elemental and reactive mercury in Southern New Hampshire, Atmos. Chem. Phys., 9, 1929-1942, doi:10.5194/acp-9-1929-2009, 2009.

Simpson, W. R., von Glasow, R., Riedel, K., Anderson, P., Ariya, P., Bottenheim, J., Burrows, J., Carpenter, L. J., Frieß, U., Goodsite, M. E., Heard, D., Hutterli, M., Jacobi, H.-W., Kaleschke, L., Neff, B., Plane, J., Platt, U., Richter, A., Roscoe, H., Sander, R., Shepson, P., Sodeau, J., Steffen, A., Wagner, T., and Wolff, E.: Halogens and their role in polar boundary-layer ozone depletion, Atmos. Chem. Phys., 7, 4375-4-418, doi:10.5194/acp-74375-2007, 2007.

Singh, H. B., Brune, W. H., Crawford, J. H., Flocke, F., and Jacob, D. J.: Chemistry and transport of pollution over the Gulf of Mexico and the Pacific: spring 2006 INTEX-B campaign overview and first results, Atmos. Chem. Phys., 9, 2301-2318, doi:10.5194/acp-9-2301-2009, 2009.

Sinnhuber, B., Rozanov, A., Sheode, N., Afe, O., Richter, A., Sinnhuber, M., Wittrock, F., Burrows, J., Stiller, G., von Clarmann, T., and Linden, A.: Global observations of stratospheric bromine monoxide from SCIAMACHY, Geophys. Res. Lett., 32, L20810, doi:10.1029/2005GL023839, 2005.

Sioris, C. E., Kovalenko, L. J., McLinden, C. A., Salawitch, R. J., Roozendael, M. V., Goutail, F., Dorf, M., Pfeilsticker, K., Chance, K., von Savigny, C., Liu, X., Kurosu, T. P., Pommereau, J. P., Boesch, H., and Frerick, J.: Latitudinal and vertical distribution of bromine monoxide in the lower stratosphere from Scanning Imaging Absorption Spectrometer for Atmospheric Chartography limb scattering measurements, J. Geophys. Res., 111, D14301, doi:10.1029/2005JD006479, 2006.

Slemr, F., Brunke, E. G., Labuschagne, C., and Ebinghaus, R.: Total gaseous mercury concentrations at the Cape Point GAW station and their seasonality, Geophys. Res. Lett., 35, L11807, doi:10.1029/2008GL033741, 2008.

Slemr, F., Ebinghaus, R., Brenninkmeijer, C. A. M., Hermann, M., Kock, H. H., Martinsson, B. G., Schuck, T., Sprung, D., van Velthoven, P., Zahn, A., and Ziereis, H.: Gaseous mercury distribution in the upper troposphere and lower stratosphere observed onboard the CARIBIC passenger aircraft, Atmos. Chem. Phys., 9, 1957-1969, doi:10.5194/acp-9-1957-2009, 2009.

Slemr, F., Brunke, E.-G., Ebinghaus, R., Kuss, J., and Edgerton, E. S.: Worldwide trend of atmospheric mercury since 1995, in preparation, 2010.

Snider, G., Raofie, F., and Ariya, P.: Effects of relative humidity and $\mathrm{CO}(\mathrm{g})$ on the $\mathrm{O}_{3}$-initiated oxidation reaction of $\mathrm{Hg}^{0}$ : kinetic and product studies, Phys. Chem. Chem. Phys., 10, 5616-5623, 2008.

Soerensen, A. L., Skov, H., Jacob, D. J., Soerensen, B. T., and Johnson, M. S.: Global concentrations of gaseous elemental mercury and reactive gaseous mercury in the marine boundary layer, Environ. Sci. Technol., 44, 425-427, 2010a.

Soerensen, A. L., Sunderland, E. M., Holmes, C. D., Jacob, D. J., Yantosca, R. M., Skov, H., Christensen, J. J., and Mason, R. P.: An improved global model for air-sea exchange of mercury: high 
concentrations over the North Atlantic, Environ. Sci. Technol., 44, 8574-8580, doi:10.1021/es102032g, 2010b.

Sommar, J., Gardfeldt, K., Stromberg, D., and Feng, X.: A kinetic study of the gas-phase reaction between the hydroxyl radical and atomic mercury, Atmos. Environ., 35, 3049-3054, 2001.

Sprovieri, F., Pirrone, N., Hedgecock, I., Landis, M., and Stevens, R.: Intensive atmospheric mercury measurements at Terra Nova Bay in Antarctica during November and December 2000, J Geophys Res, 107, 4722, doi:10.1029/2002JD002057, 2002.

Stamenkovic, J., Lyman, S., and Gustin, M. S.: Seasonal and diel variation of atmospheric mercury concentrations in the Reno (Nevada, USA) airshed, Atmos. Environ., 41, 6662-6672, doi:10.1016/j.atmosenv.2007.04.015, 2007.

Steffen, A., Schroeder, W., Macdonald, R., Poissant, L., and Konoplev, A.: Mercury in the Arctic atmosphere: An analysis of eight years of measurements of GEM at Alert (Canada) and a comparison with observations at Amderma (Russia) and Kuujjuarapik (Canada), Sci. Total. Environ., 342, 185-198, 2005.

Steffen, A., Douglas, T., Amyot, M., Ariya, P., Aspmo, K., Berg, T., Bottenheim, J., Brooks, S., Cobbett, F., Dastoor, A., Dommergue, A., Ebinghaus, R., Ferrari, C., Gardfeldt, K., Goodsite, M. E., Lean, D., Poulain, A. J., Scherz, C., Skov, H., Sommar, J., and Temme, C.: A synthesis of atmospheric mercury depletion event chemistry in the atmosphere and snow, Atmos. Chem. Phys., 8, 1445-1482, doi:10.5194/acp-8-1445-2008, 2008.

Strahan, S. E., Duncan, B. N., and Hoor, P.: Observationally derived transport diagnostics for the lowermost stratosphere and their application to the GMI chemistry and transport model, Atmos. Chem. Phys., 7, 2435-2445, doi:10.5194/acp-7-2435-2007, 2007.

Streets, D., Zhang, Q., and Wu, Y.: Projections of global mercury emissions in 2050, Environ. Sci. Technol., 43, 2983-2988, doi:10.1021/es802474j, 2009.

Strode, S. A., Jaegle, L., Selin, N. E., Jacob, D. J., Park, R. J., Yantosca, R. M., Mason, R. P., and Slemr, F.: Air-sea exchange in the global mercury cycle, Global Biogeochem. Cy., 21, GB1017, doi:10.1029/2006GB002766, 2007.

Sunderland, E. M. and Mason, R. P.: Human impacts on open ocean mercury concentrations, Global Biogeochem. Cy., 21, GB4022, doi:10.1029/2006GB002876, 2007.

Swartzendruber, P. C., Chand, D., Jaffe, D. A., Smith, J., Reidmiller, D., Gratz, L., Keeler, J., Strode, S., Jaegle, L., and Talbot, R.: Vertical distribution of mercury, CO, ozone, and aerosol scattering coefficient in the Pacific Northwest during the spring 2006 INTEX-B campaign, J. Geophys. Res., 113, D10305, doi:10.1029/2007JD009579, 2008.

Talbot, R., Mao, H., Scheuer, E., Dibb, J., and Avery, M.: Total depletion of $\mathrm{Hg}^{0}$ in the upper troposphere-lower stratosphere, Geophys. Res. Lett., 34, L23804, doi:10.1029/2007GL031366, 2007.

Talbot, R., Mao, H., Scheuer, E., Dibb, J., Avery, M., Browell, E., Sachse, G., Vay, S., Blake, D., Huey, G., and Fuelberg, H.: Factors influencing the large-scale distribution of $\mathrm{Hg}^{0}$ in the Mexico City area and over the North Pacific, Atmos. Chem. Phys., 8, 2103-2114, doi:10.5194/acp-8-2103-2008, 2008.

Talbot, R. W. and Mao, H.: Boreal forest fires and pyrocumulonimbus convection as a source of $\operatorname{Hg}(0)$ to the troposphere, Eos Transactions, Fall Meeting Suppl, 90, A43A-0228, 2009.

Telmer, K. H. and Veiga, M. M.: World emissions of mercury from artisanal and small scale gold mining, in: Mercury Fate and Transport in the Global Atmosphere, edited by: Pirrone, N. and Mason, R. P., chap. 6, Springer, 2009.

Temme, C., Einax, J., Ebinghaus, R., and Schroeder, W.: Measurements of atmospheric mercury species at a coastal site in the Antarctic and over the South Atlantic Ocean during polar summer, Environ. Sci. Technol., 37, 22-31, 2003.

Temme, C., Blanchard, P., Steffen, A., Banic, C., Beauchamp, S., Poissant, L., Tordon, R., and Wiens, B.: Trend, seasonal and multivariate analysis study of total gaseous mercury data from the Canadian atmospheric mercury measurement network (CAMNet), Atmos. Environ., 41, 5423-5441, doi:10.1016/j.atmosenv.2007.02.021, 2007.

Thornton, B., Toohey, D., Avallone, L., Harder, H., Martinez, M., Simpas, J., Brune, W., and Avery, M.: In situ observations of $\mathrm{ClO}$ near the winter polar tropopause, J. Geophys. Res., 108, 8333, doi:10.1029/2002JD002839, 2003.

Valente, R., Shea, C., Humes, K., and Tanner, R.: Atmospheric mercury in the Great Smoky Mountains compared to regional and global levels, Atmos. Environ., 41, 1861-1873, 2007.

Van Loon, L., Mader, E., and Scott, S.: Reduction of the aqueous mercuric ion by sulfite: UV spectrum of $\mathrm{HgSO}_{3}$ and its intramolecular redox reaction, J. Phys. Chem. A, 104, 1621-1626, 2000.

Van Roozendael, M., Wagner, T., Richter, A., Pundt, I., Arlander, D., Burrows, J., Chipperfield, M., Fayt, C., Johnston, P., Lambert, J., Kreher, K., Pfeilsticker, K., Platt, U., Pommereau, J., Sinnhuber, B., Tornkvist, K., and Wittrock, F.: Intercomparison of $\mathrm{BrO}$ measurements from ERS-2 GOME, ground-based and balloon platforms, Adv. Space Res., 29, 1661-1666, 2002.

Vijayaraghavan, K., Karamchandani, P., Seigneur, C., Balmori, R., and Chen, S.-Y.: Plume-in-grid modeling of atmospheric mercury, J. Geophys. Res., 113, D24305, doi:10.1029/2008JD010580, 2008.

von Glasow, R., Sander, R., Bott, A., and Crutzen, P.: Modeling halogen chemistry in the marine boundary layer -1 . Cloud-free MBL, J. Geophys. Res., 107, 4341, doi:10.1029/2001JD000942, 2002.

von Glasow, R., von Kuhlmann, R., Lawrence, M. G., Platt, U., and Crutzen, P. J.: Impact of reactive bromine chemistry in the troposphere, Atmos. Chem. Phys., 4, 2481-2497, doi:10.5194/acp4-2481-2004, 2004.

Wan, Q., Feng, X., Lu, J., Zheng, W., Song, X., Han, S., and Xu, H.: Atmospheric mercury in Changbai Mountain area, northeastern China I. The seasonal distribution pattern of total gaseous mercury and its potential sources, Environ. Res., 109, 201-206, doi:10.1016/j.envres.2008.12.001, 2009.

Wangberg, I., Munthe, J., Berg, T., Ebinghaus, R., Kock, H. H., Temme, C., Bieber, E., Spain, T. G., and Stolk, A.: Trends in air concentration and deposition of mercury in the coastal environment of the North Sea Area, Atmos. Environ., 41, 2612-2619, doi:10.1016/j.atmosenv.2006.11.024, 2007.

Warwick, N., Pyle, J., Carver, G., Yang, X., Savage, N., O'Connor, F., and Cox, R.: Global modeling of biogenic bromocarbons, J. Geophys. Res., 111, D24305, doi:10.1029/2006JD007264, 2007.

Weiss-Penzias, P., Jaffe, D., Swartzendruber, P., Hafner, W., Chand, D., and Prestbo, E.: Quantifying Asian and biomass burning sources of mercury using the $\mathrm{Hg} / \mathrm{CO}$ ratio in pollution plumes observed at the Mount Bachelor Observatory, Atmos. Environ., 
41, 4366-4379, doi:10.1016/j.atmosenv.2007.01.058, 2007.

Weiss-Penzias, P., Gustin, M. S., and Lyman, S. N.: Observations of speciated atmospheric mercury at three sites in Nevada: Evidence for a free tropospheric source of reactive gaseous mercury, J. Geophys. Res., 114, D14302, doi:10.1029/2008JD011607, 2009.

Wesely, M.: Parameterization of surface resistances to gaseous dry deposition in regional-scale numerical models, Atmos. Environ., 23, 1293-1304, 1989.

WMO: Scientific Assessment of Ozone Depletion: 2006, Tech. Rep. 50, Global Ozone Research and Monitoring Project, Geneva, Switzerland, 2007.

Xie, Z.-Q., Sander, R., Pöschl, U., and Slemr, F.: Simulation of atmospheric mercury depletion events (AMDEs) during polar springtime using the MECCA box model, Atmos. Chem. Phys., 8, 7165-7180, doi:10.5194/acp-8-7165-2008, 2008.
Yang, X., Cox, R., Warwick, N., Pyle, J., Carver, G., O'Connor, F., and Savage, N.: Tropospheric bromine chemistry and its impacts on ozone: A model study, J. Geophys. Res., 110, D23311, doi:10.1029/2005JD006244, 2005.

Yang, X., Pyle, J. A., Cox, R. A., Theys, N., and Van Roozendael, M.: Snow-sourced bromine and its implications for polar tropospheric ozone, Atmos. Chem. Phys., 10, 7763-7773, doi:10.5194/acp-10-7763-2010, 2010.

Yatavelli, R. L. N., Fahrni, J. K., Kim, M., Crist, K. C., Vickers, C. D., Winter, S. E., and Connell, D. P.: Mercury, PM2.5 and gaseous co-pollutants in the Ohio River Valley region: Preliminary results from the Athens supersite, Atmos. Environ., 40, 6650-6665, doi:10.1016/j.atmosenv.2006.05.072, 2006.

Zhang, H., Lindberg, S., Marsik, F., and Keeler, G.: Mercury air/surface exchange kinetics of background soils of the Tahquamenon River watershed in the Michigan Upper Peninsula, Water Air Soil Poll., 126, 151-169, 2001. 